\title{
Zoophycos in storm-affected environments: a case study from lower Maastrichtian deposits of the Mateur-Beja area (Northern Tunisia)
}

\author{
Fehmy Belghouthi ${ }^{\mathrm{a}}$, Andreas Wetzel $^{\mathrm{b}}$, Hédi Zouaric and Rekaya-Selwa Jeddi ${ }^{\mathrm{d}}$ \\ a Faculté des Sciences de Bizerte (FSB), Université de Carthage, Bizerte, Tunisia; Email: \\ fehmy.belghouthi@yahoo.fr \\ ${ }^{\mathrm{b}}$ Departement Umweltwissenschaften - Geologie, Universität Basel, Basel, Switzerland; \\ ${ }^{c}$ Laboratoire de traitement des eaux naturelles LDTEN - Centre de Recherche et des \\ Technologies des Eaux de Borj-Cédria (CERTE), Soliman, Tunisia; \\ d Entreprise Tunisienne d'Activités Pétroliéres (ETAP), Tunis, Tunisia
}

Published 2020 in ICHNOS, 27: 200-220

doi: $10.1080 / 10420940.2020 .1730360$

\begin{abstract}
The lower Maastrichtian deposits of the Mateur-Beja area in northern Tunisia are mainly composed of fine-grained marl and limestone alternations occasionally interbedded by coarsegrained calcarenites and gravel deposits. In the coarse-grained intervals sedimentary structures are indicative of storm-induced high-energy currents in an outer ramp to slope setting and of local reworking by bottom currents in the basin. In deeper environments, finegrained sediments accumulated mainly while settling from storm-induced suspensions. The lower Maastrichtian deposits contain abundant Zoophycos exhibiting two main morphotypes, skirt-shaped Zoophycos in deposits around storm-wave base and tongue-shaped Zoophycos in somewhat deeper sediments. The types differ in burrow architecture, morphology of lobes, and size of structural elements. These differences are attributed to different behavioral programs modulated by the availability of benthic food that decreased seaward. Stormaffected environments seem to be a prerequisite for these Zoophycos-producers to choose their habitat.
\end{abstract}

KEYWORDS: Zoophycos; lower Maastrichtian; storm deposits; Tunisia

\section{Introduction}

The conspicuous trace fossil Zoophycos is reported from ancient and modern marine environments (Seilacher 1967; Simpson 1970; Wetzel and Werner 1980; Kotake 1989; Bromley, Ekdale, and Asgaard 1999; Bromley and Hanken 2003; Ekdale and Lewis 1991; Gaillard and Olivero 1993; Olivero 1996; Miller and d'Alberto 2001; Löwemark et al. 2004; Löwemark 2015; Richiano 2015; Zhang, Fan, and Gong 2015; Monaco et al. 2017, and references herein). However, the architecture of the burrow system described in publications is commonly interpretative, while only some characteristic parts of Zoophycos were observed, but not the complete trace (e.g., Olivero 1996; Miller and d'Alberto 2001; Monaco et al. 2017). Due to their high morphological variability and complexity the traces are ascribed to the Zoophycos group (Uchman and Demírcan 1999). Accordingly, many models and concepts exist about the construction of the burrow, the behavior and the type of producer. It is still a matter of debate if different Zoophycos tracemakers or only one that can change its behavior in response to the environmental conditions accomplished the large varieties in burrow morphology. The response of Zoophycos tracemakers to varying environmental conditions is well documented in modern deep-sea sediments (Löwemark et al. 2004; Wetzel 2010; Wetzel, 
Tjallingii, and Wiesner 2011; Rodríguez-Tovar, Löwemark, and Pardo-Igúzquiza 2011; Dorador, Wetzel, and Rodríguez-Tovar 2016). These studies outline close relationships between Zoophycos, seasonal deposition of organic-matter and varying sedimentation rates.

In the Mateur-Beja area in the northern Tunisia, Zoophycos occurs locally in high abundance in lower Maastrichtian pelagic and hemipelagic carbonate series composed of limestone, marl, white chalk and chalky limestone. Zoophycos is more abundant in marl and limestone than in white chalk and chalky limestone. It is the purpose of the present study (i) to decipher the depositional environment of the lower Maastrichtian deposits, (ii) to describe the occurrence and morphology of Zoophycos burrows, (iii) to derive some ethological aspects of the producer, (iv) to unravel the relationship between trace abundance and environmental setting and (v) to elucidate the environmental significance of Zoophycos in the studied deposits.

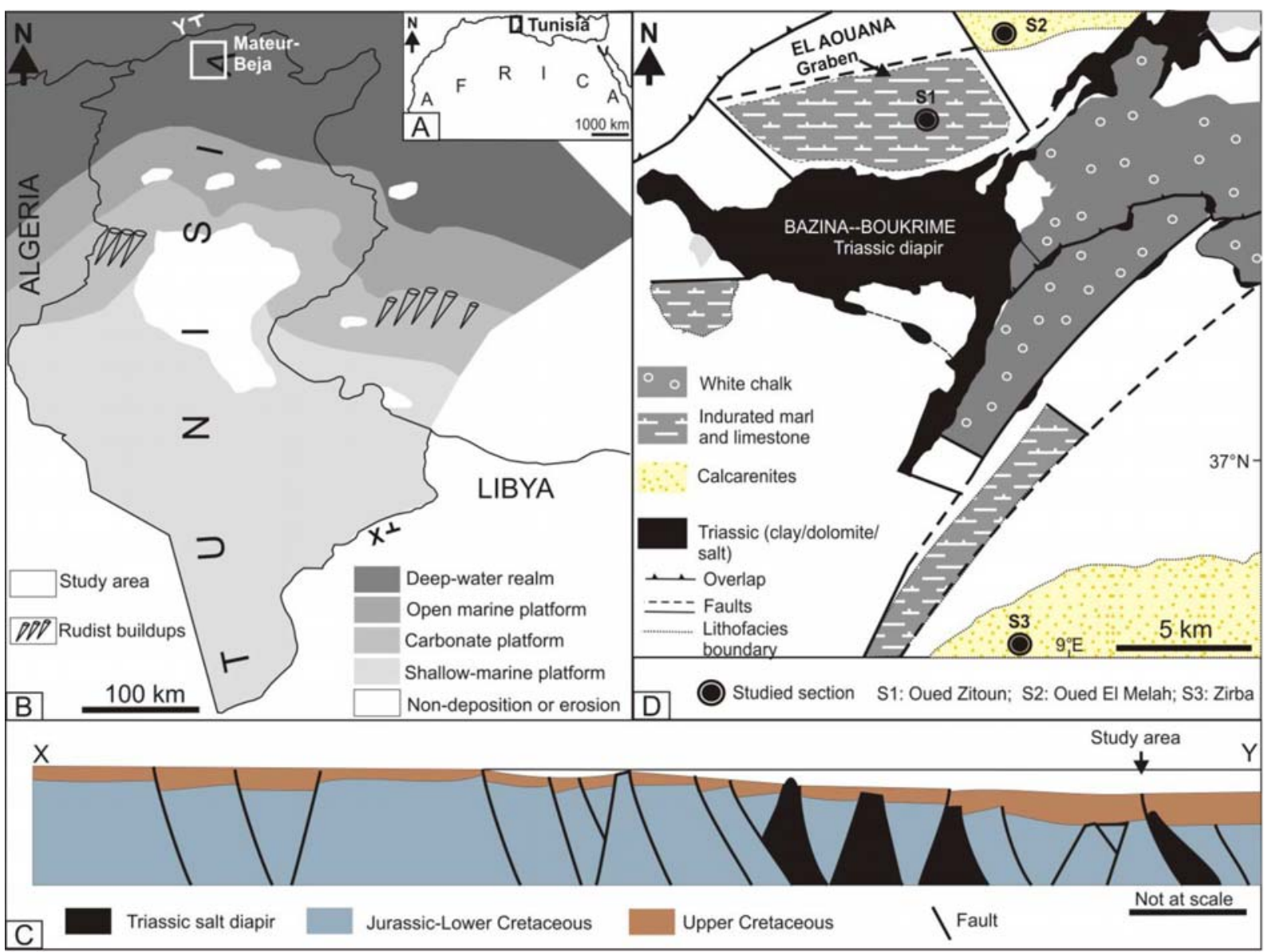

Figure 1. Study area. (A) Location of Tunisia (black frame - area shown in (B)). (B) Paleogeographic map of the Tunisian realm during the Late Cretaceous (after Mejri, Burollet, and Ferjani 2006); white frame indicates location of the study area shown in (D); X, Y represent end points of cross-section shown in (C). (C) Schematic structural section across the Tunisian margin (after Martinez and Truillet 1987). (D) Paleogeographic situation in the study area in the Mateur-Beja area during the lower Maastrichtian and location of studied sections.

\section{Geologic setting}

During the Late Cretaceous, the Tunisian domain was a part of the southern Tethys realm (Figure 1A, e.g., Burollet 1956; Negra 1994; Chaabani 1994; Mejri, Burollet, and Ferjani 
2006). A shallow inner platform established in its southern part, while the central part represented a carbonate ramp/shelf with reef buildups (Negra 1994). To the north, there was a deep-water province subdivided into (i) the northeastern "Pelagian domain" extending towards the southeast and, (ii) the relatively deeper northwestern "Tunisian trough" extending towards the northwest (Burollet 1956). The Tunisian trough was structured during the Late Cretaceous by tilted blocs dipping towards north or south, while subsidence increased towards the north and northwest (Figure 1B). Bloc tilting very likely resulted from tectonic extension interacting with local halokinetic movements of Triassic salt (Dlala 2002; Ben Mehrez, Kacem, and Dlala 2009). In central and northern Tunisia, several synsedimentary grabens were interpreted to have formed due to such tectonic processes and they acted as local depocenters (Martinez and Truillet 1987; Negra 1994; Ben Mehrez, Kacem, and Dlala 2009; Belghouthi 2014). Among them, the E-W to NE-SW trending El Aouana graben developed during the Late Cretaceous along the border of Bazina-Boukrime salt diapir (Ben Mehrez, Kacem, and Dlala 2009; Belghouthi 2014). This graben contains about 600m of CampanianMaastrichtian sediments, which are twice as thick as the same series outside the graben (Belghouthi 2014). Synsedimentary subsidence of the grabens influenced the facies distribution while mainly fine-grained deposits accumulated in the graben center and coarsegrained deposits and chalk on the graben shoulders (Figure 1C).

In northwestern Tunisia, the Upper Campanian-Lower Maastrichtian sediment series, known as Abiod Formation (Burollet 1956), consists of an upper and a lower limestone member separated by a dark-grey marl member (Figure 2). The upper limestone member is a $80-200 \mathrm{~m}$ thick and Early Maastrichtian in age (Kujawski 1969; Negra 1994). It is composed of two main lithological units; the lower marl-dominated unit comprises marl and limestone couplets and is particularly rich in Zoophycos, and the upper unit essentially consists of chalky and nodular chalky limestone containing inoceramid bivalves (Belghouthi, Zouari, and Jeddi 2019). The present study focuses on the lower marl unit and its lateral equivalents that exhibits abundant Zoophycos and, therefore, is called Zoophycos-bearing unit (ZU; Figure 2).

\section{Methods}

Three sections, Oued El Melah, Oued Zitoun and Zirba, were investigated and correlated. Lithology, sedimentary structures, and fossil content were described and interpreted. 90 samples were collected from limestones and marls; 71 samples were prepared for petrographic analysis and 19 samples for TOC analysis. TOC was measured while applying pyrolysis of rock powder from $100^{\circ} \mathrm{C}$ to $800^{\circ} \mathrm{C}$ by using a Rock-Eval 6 equipment.

Zoophycos occurs abundantly in all three localities. In the outcrops, 52 specimens were analysed, measured, and classified as well as sampled. Zoophycos represents a multilobate spreite burrow usually composed of several elementary or "basic lobes". The latter were evaluated to distinguish and to classify the various Zoophycos morphotypes while considering morphology of lobes, major lamellae, minor lamellae, and marginal tubes as main structural elements (Zhang, Fan, et al. 2015; Zhang, Shi, and Gong 2015; Monaco et al. 2017).

The abundance of Zoophycos in outcrops was evaluated by counting the number of traces per unit area in cross-section as suggested by Olivero (1996), but using only four classes: rare $-<2$ traces $/ 10 \mathrm{~m}^{2}$, common -1 trace $/ 2 \mathrm{~m}^{2}$, abundant -1 trace $/ \mathrm{m}^{2}$, very abundant - closelyspaced traces in $100 \mathrm{~cm}^{2}$. 


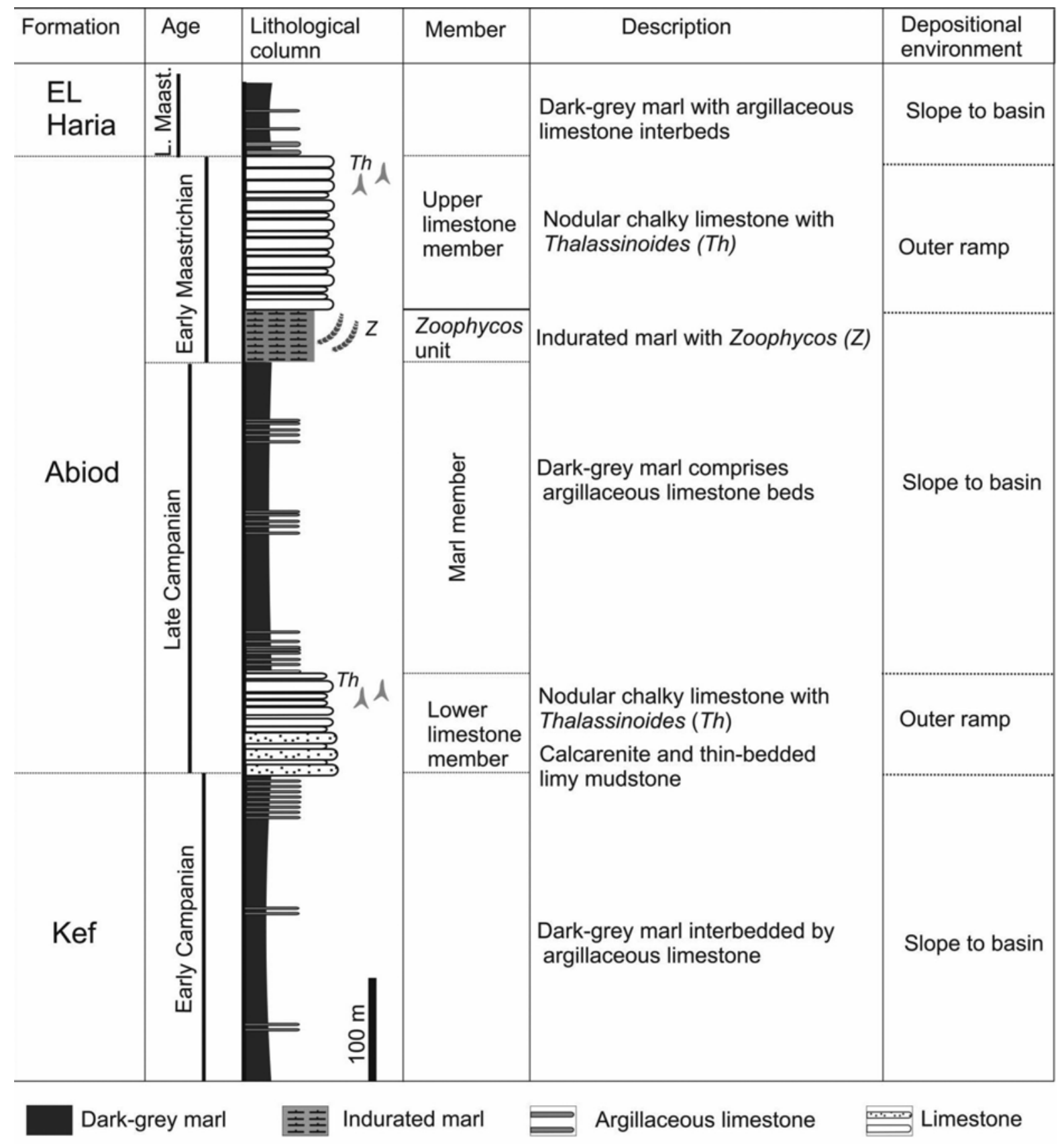

Figure 2. Lithostratigraphic log of the Upper Campanian-Lower Maastrichtian Abiod Formation in the study area.

4. Sedimentary characteristics and depositional environment of the Zoophycos unit (ZU)

The ZU consists of 21-45m thick marl and fine-grained limestone alternations and occasionally intercalated calcarenites and gravel intervals (Figure 3). Coarse-grained intervals represent about $20-40 \%$ of the succession at Zirba and Oued El Melah and $\sim 10 \%$ at Oued Zitoun. Depending on sedimentary structures, grain size and strata geometry, three lithofacies are distinguished. 


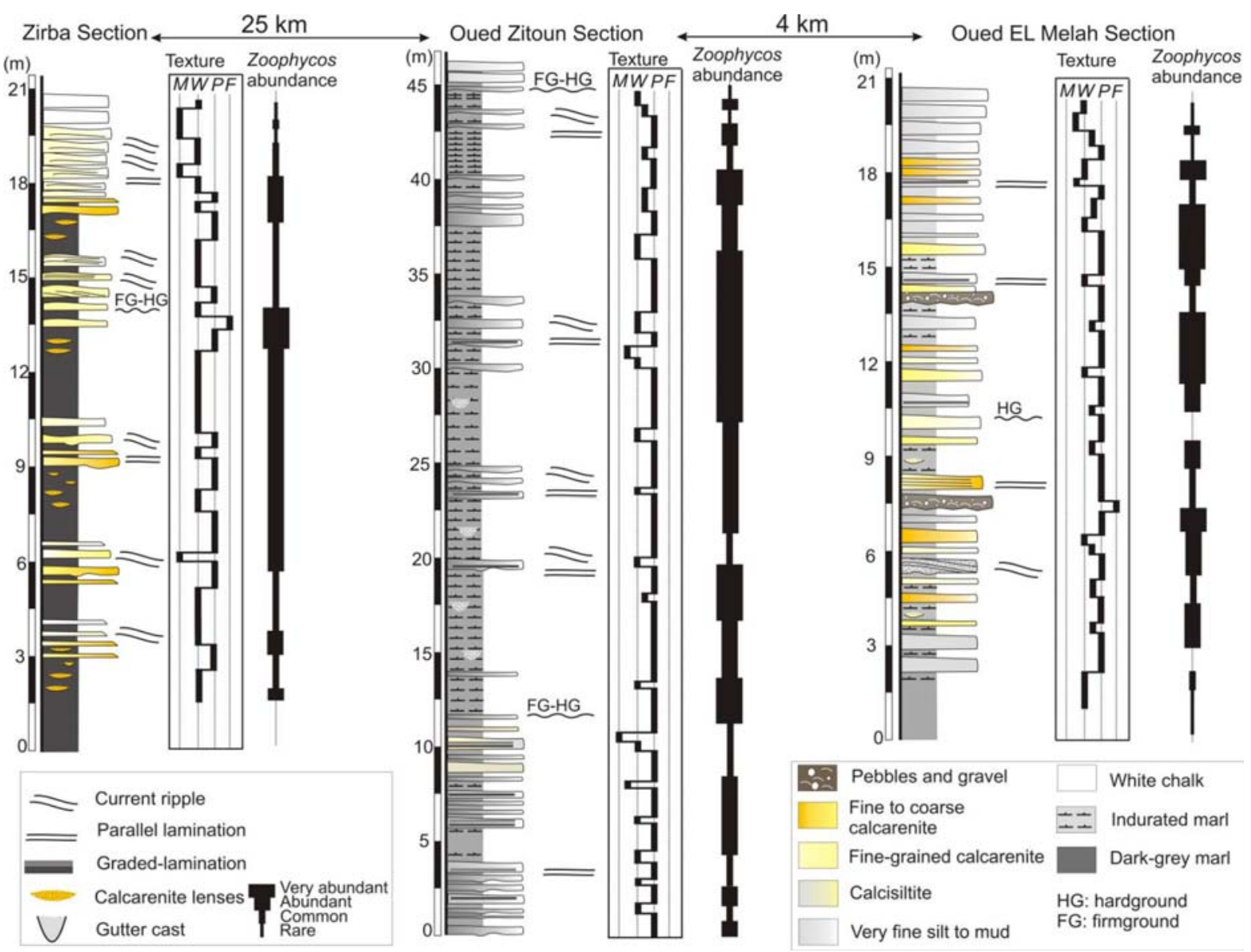

Figure 3. Lithology, microfacies, and Zoophycos abundance observed in the three studied sections (see Figure 1 for location). The abundance scale represents average values measured at different levels.

\subsection{Lithofacies 1}

\subsubsection{Observations}

Lithofacies 1 occurs in the Zirba section. It is composed of 20-60 cm thick, normally graded, tripartite coarse calcarenite to calcisiltite beds interbedded within meter-thick silty marl (Figure 3). The basal calcarenitic division is lenticular in shape, $8-20 \mathrm{~cm}$ thick, of massive appearance, poorly to moderately sorted and exhibits scattered lithoclasts and mudclasts. The lower surface is erosional, planar or accentuated by $8-14 \mathrm{~cm}$ wide and $2-5 \mathrm{~cm}$ deep gutter casts. The middle division is $10-25 \mathrm{~cm}$ thick and consists of cross-stratified fine calcarenite structured by wave and current ripples. The latter exhibit high- and low-angle asymmetric undulations and rounded crests. In cross-section, the high-angle undulating ripples display stacked and aggrading sigmoidal backset laminae (Figure 4). The wave ripples have peaked crests and steep sides. The upper division is composed centimeter to decimeter thick, structureless calcisiltite that passes upward into silty marl containing sand lenses $10-25 \mathrm{~cm}$ in length.

\subsubsection{Interpretation}

Erosional structures including gutter casts at the base, cross-stratification, normal grading, internal erosional surface, low-angle sigmoidal cross-lamination and bidirectional currentindicators as well as wave-ripples at the top are indicative of unidirectional and combined oscillatory flow (Myrow and Southard 1996). This flow is characteristic of tempestites documenting storm influence (Harms 1975; Aigner 1982; Myrow and Southard 1996; Dumas, 
Arnott, and Southard 2005, Dumas and Arnott 2006; Basilici, Vieira de Luca, and Poiré 2012).

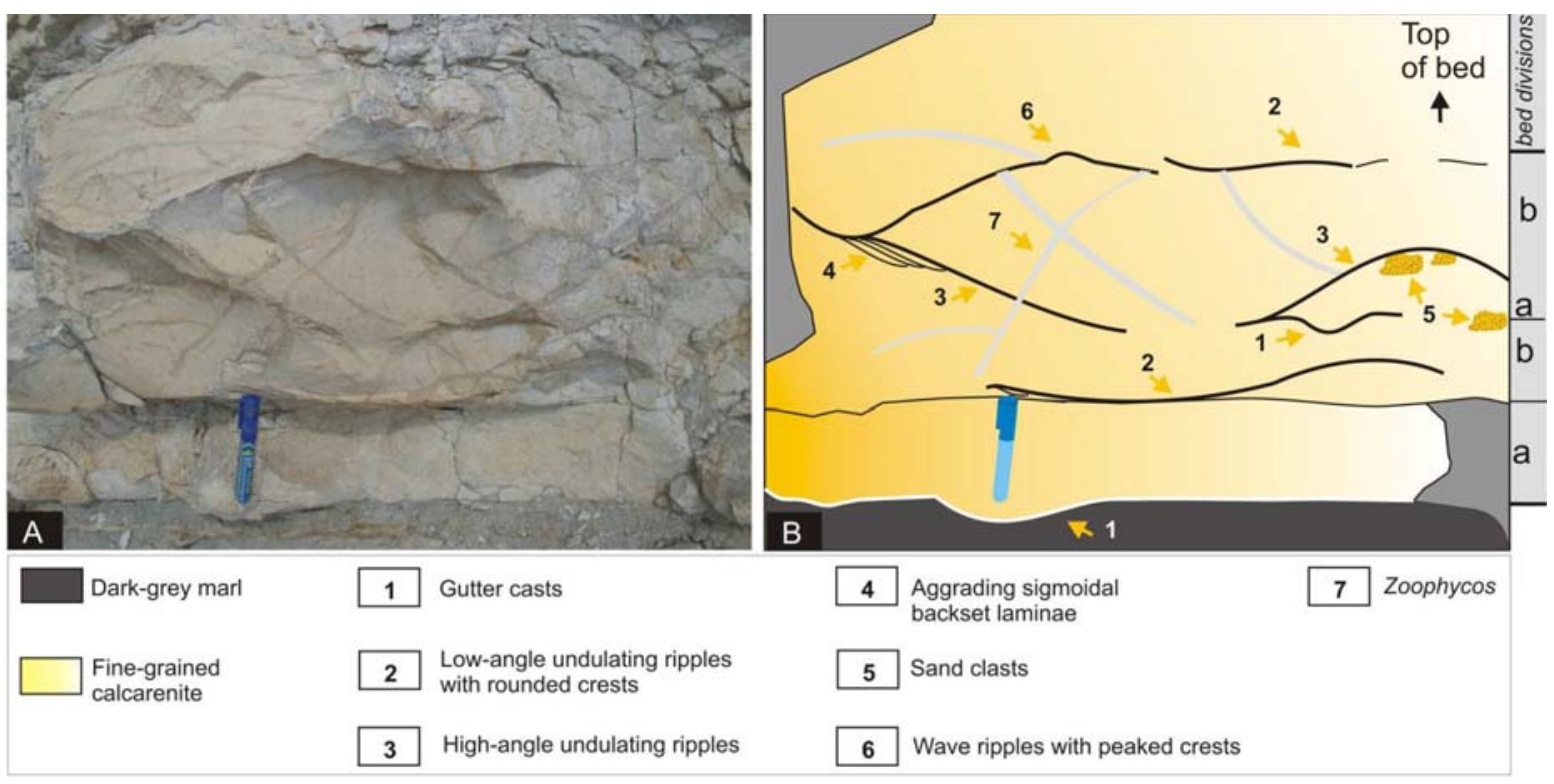

Figure 4. Lithofacies 1. A. Fine sandstone amalgamated beds composed of three main bed-divisions: a lower bed-division (a) composed of structureless sandstone with gutter casts; an intermediate beddivision (b) marked by dome-like bedforms composed of sigmoidal ripples and sand clasts; an upper bed-division (c) composed of wave ripples with peaked and rounded crests. B. Line interpretations. Scale: $P e n=14 \mathrm{~cm}$.

\subsection{Lithofacies 2}

4.2.1. Observations

Lithofacies 2 is present in the Oued Zitoun section. Characteristic are normally graded, tripartite beds having an erosional base and wave ripples on top. Above an erosional base accentuated by gutter casts, the basal division consists of $12-20 \mathrm{~cm}$ thick, coarse- to mediumgrained calcarenites containing scattered bioclasts dominated by inoceramid prisms. The middle bed-division comprises $0.5-9 \mathrm{~cm}$ thick, fine-grained sediments commonly composed of alternating mud-rich and dark-colored laminae (Figure 5A). These planar to slightly undulating laminae are 1-7 cm thick and commonly show asymmetric, low angle, sigmoidal, $1-2 \mathrm{~cm}$ high and $15-30 \mathrm{~cm}$ long ripples and symmetric, $0.2-0.5 \mathrm{~cm}$ high and $3-8 \mathrm{~cm}$ long wave ripples having peaked crests (Figure 5B). The upper bed-division comprises 5-70 cm thick, very fine-grained limestone and bioturbated marl. Occasionally, a hardground/ firmground developed on top of the bed.

\subsubsection{Interpretation}

Structural and textural grading of beds suggests deposition by generally decelerating, but short-term accelerating flows characterized by both unidirectional and oscillatory flow components. As above, these beds are interpreted to represent tempestites (e.g., Aigner 1982; Myrow and Southard 1996). The upper bed division composed of ungraded and bioturbated very fine mud probably was formed by settling from suspension and post-event 'hemipelagic rain'. 


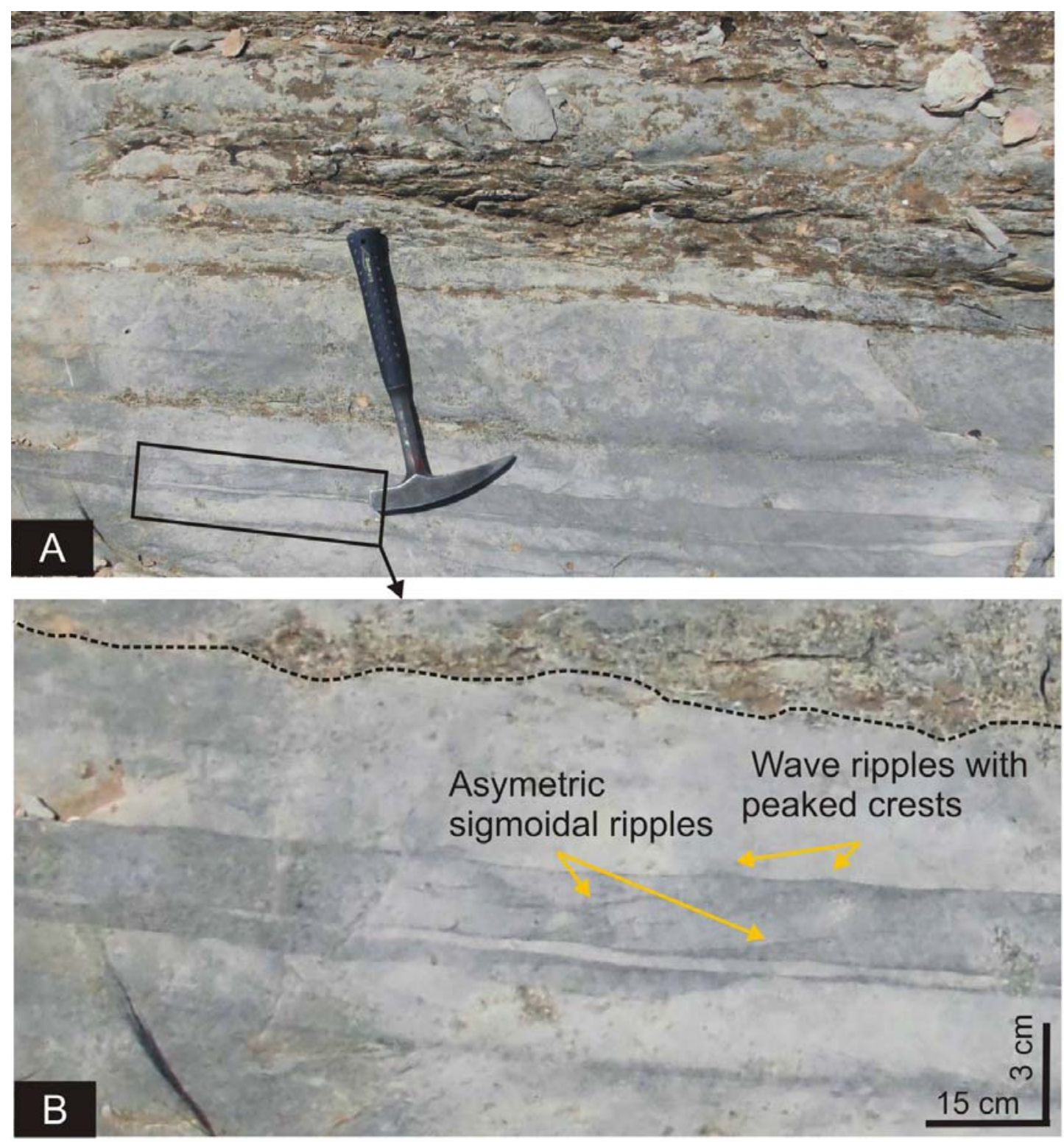

Figure 5. Lithofacies 2. (A) Fine-grained limestone and marl levels marked by dark-colored planar lamination. (B) Close-up view of dark-colored lamination showing light-grey and dark-grey planar laminations composed of asymmetrical sigmoidal ripples and wave ripples with peaked crests. Scale: Hammer $=34 \mathrm{~cm}$.

\subsection{Lithofacies 3}

4.3.1. Observations

Lithofacies 3 occurs in the Oued El Melah section and comprises a coarse calcarenite lithosubfacies and fine-grained calcilutite lithosubfacies.

The coarse-grained calcarenite lithosubfacies consists of $1-30 \mathrm{~cm}$ thick, laminated, tripartite beds alternating with $25-40 \mathrm{~cm}$-thick structureless calcilsiltitic intervals. The basal, coarsegrained bed-division is $1-6 \mathrm{~cm}$ thick, lenticular in shape and exhibits top-eroded sigmoidal backset laminae (Figure 6A, B). The middle, fine calcarenitic bed-division is $15-30 \mathrm{~cm}$ thick, moderately to well sorted and commonly displays parallel and planar lamination as well as low-angle to planar current-ripple lamination. The upper calcisiltitic bed-division is structureless, but commonly shows groove casts at the base and dish structures and floating pebbles within the interval (Figure 6A, B). 
The fine-grained calcilutite lithosubfacies is characterized by bipartite beds composed 15-40 $\mathrm{cm}$ thick calcilutite and marl layers, occasionally alternating with $3-8 \mathrm{~cm}$ thick calcarenites that are either inversely graded or cross-laminated. Inversely graded intervals are $5-15 \mathrm{~cm}$ thick and contain moderately sorted bioclast gravel at the top (Figure 6C). Cross-laminated intervals display top-eroded low-angle sigmoidal backset laminae separated by erosional surfaces (Figure 6D). In both cases, the upper bed-division consists of $20-50 \mathrm{~cm}$ thick, usually bioturbated calcilutite and marl. Beds of the calcilutite lithosubfacies are amalgamated and exhibit numerous internal slightly undulating erosional surfaces. The calcilutite is rich in planktonic tests. On the top of a bed, occasionally a hardground is developed.

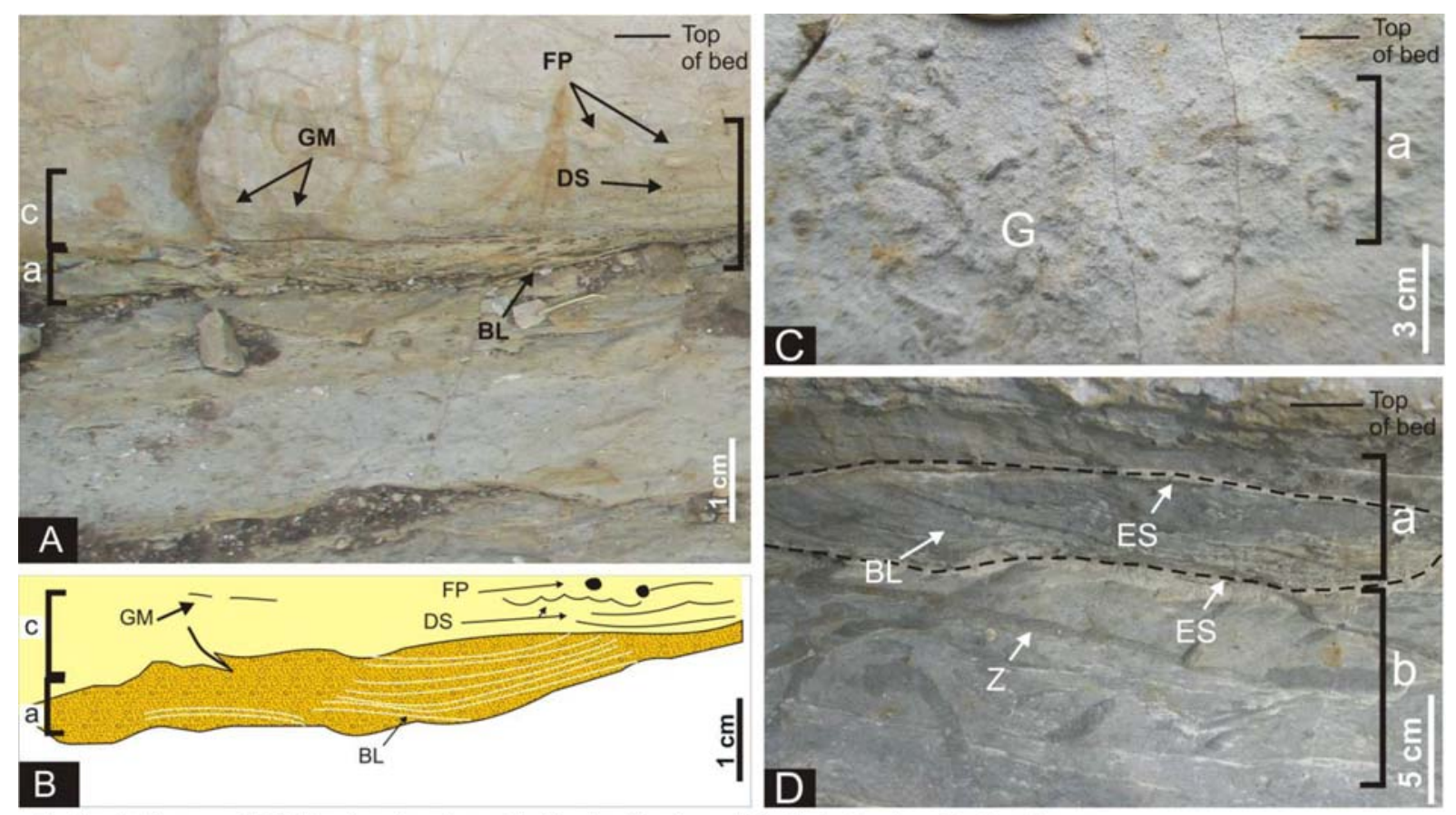

G: Bioclastic gravel; ES: Erosional surface; BL: Backset laminae; DS: Dish structure; Z: Zoophycos

(a) lower and (b) upper bed-division

Figure 6. Lithofacies 3 (calcarenite lithosubfacies). (A) Field photograph and (B) line drawing of coarse-grained, laminated calcarenite basal bed-division (a), overlain by fine calcisiltite of the upper bed-division (c) marked by groove marks, dish structures and floating pebbles. (C, D) Calcalutite lithosubfacies showing bioclastic gravel of the lower calcarenite bed-division (a), overlain by intermediate bed-division (b) marked by backset laminae which overlain very fine-grained marl level containing Zoophycos of the uppermost bed-division (d). Note that the two bed-divisions are separated by erosional surface.

\subsubsection{Interpretation}

In the calcarenite lithosubfacies, sedimentary structures suggest deposition mainly from unidirectional traction currents, in particular the basal coarse-grained bed-division with backset laminae. The latter imply suspension settling influenced by relatively weak unidirectional currents (Dumas, Arnott, and Southard 2005). Inverse grading and enrichment of bioclastic gravel at the top of beds implies accelerating flows (e.g. Mulder and Alexander 2001). Groove casts and floating pebbles within the upper bed-division indicate bed-load transport by traction currents. Dish structures might be indicative of rapid deposition from such traction currents (Allen 1984). In fine-grained lithosubfacies, the inversely graded calcarenites are interpreted to have formed during the initial phase of flow acceleration 
(Kneller 1995). The cross-laminated calcarenites point to weak unidirectional traction currents. Planar erosional surfaces within the amalgamated calcilutite beds indicate recurrent erosional phases by relatively steady-energy erosional traction currents. The high content of planktonic shells implies an offshore sediment source.

In lithofacies 3, the absence of oscillatory-flow indicators implies deposition below storm-wave base. The reworking and deposition of sediment below the storm-wave base is interpreted to be modulated by bottom currents rather than storm currents. Corresponding sedimentary structures are present in lithofacies 3, like horizontal planar lamination, climbing ripples (equivalent of top-eroded backset laminae), inverse grading, traction current-induced structures such as groove marks and preferentially-oriented floating pebbles as well as internal erosional structures (e.g. Shanmugam 2013; 2016; 2017; Rebesco et al. 2014).

\subsection{Depositional environment of the Zoophycos-bearing unit (ZU)}

Based on sedimentary structures and sediment composition, the $\mathrm{ZU}$ is interpreted to have formed within a carbonate ramp setting around storm-wave base (Figure 7). In lithofacies 1, the supercritical-flow structures point to rapid unidirectional flows typically occurring on a relative inclined slope above storm-wave base. For lithofacies 2, the dominance of muddy material as well as the relative uniform grain size suggest a gently sloped or even flat depositional setting located at or slightly below storm-wave base. In somewhat deeper settings, sedimentary structures suggest bottom currents to have influenced formation of lithofacies 3. The significant thickening of the $\mathrm{ZU}$ in the Oued Zitoun section records synsedimentary subsidence of the El Aouana Graben.

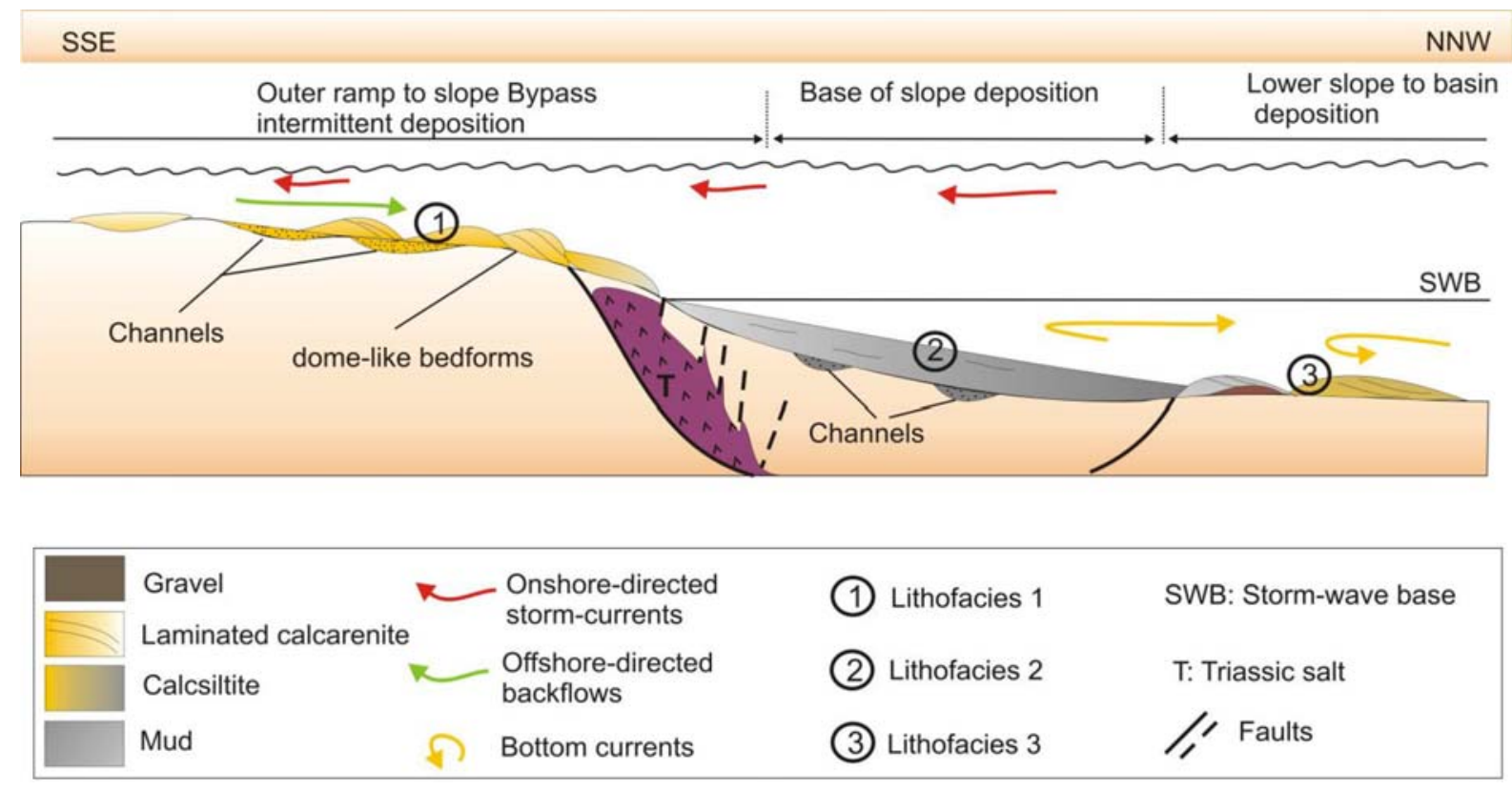

Figure 7. Interpretation of the depositional environment of the Zoophycos-bearing unit (ZU).

\section{Observations on Zoophycos}

\subsection{Zoophycos abundance}

The abundance of Zoophycos varies with lithology (Figure 3). In the Zirba section, Zoophycos is common to abundant in fine-grained limestone and marl couplets, and rare in white chalk deposits. In the Oued Zitoun, Zoophycos is generally abundant to very abundant in marl and limestone couplets, common to abundant in firmground/hardgrounds and, common to rare in 
chalky limestones. In the Oued El Melah section, Zoophycos are very abundant in marl, common to abundant in calcarenite beds, but rare in chalky limestone and absent in hardgrounds. Generally, in marl-limestone couplets, Zoophycos occur throughout the marl and in the upper third of a limestone bed.

\subsection{Morphology of Zoophycos burrows}

Although the studied Zoophycos are usually incomplete owing to erosion, the large number of observations allowed to combine them to rather complete Zoophycos burrows. Zoophycos represents a three-dimensional, $80-100 \mathrm{~cm}$ deep penetrating structure consisting of helical and/or planar elements. Most of these traces are multilobate and are composed of several lobes that are connected to a shaft. Four main structural elements were used to differentiate the burrow morpholoy;

- basic lobe - a protrusive spreite extending beyond the apex that is repeatedly produced to construct the burrow (e.g., Monaco et al. 2017);

- marginal tube - remnant of the spreite causative tube outlining a lobe externally (e.g., Wetzel and Werner, 1980);

- major (or primary) lamellae - elongated ribs extending from the apex to the marginal tube (e.g., Zhang, Shi, et al. 2015), and major interspaces - elongated concave groove-like structures, parallel to the major lamellae and extending from the apex to the marginal tube;

- minor lamellae - crescent-shaped, obliquely oriented laminae between the major lamellae (e.g., Olivero and Gaillard 2007).

While the lobes vary in morphology they were used as criterion to distinguish various Zoophycos morphotypes. Two types of basic lobes are distinguished, skirt-like " $\mathrm{S}$ " and tongue-like "T" (Table 1).

\begin{tabular}{|c|c|c|c|c|c|c|c|}
\hline & \multirow[t]{2}{*}{ Morphology } & \multicolumn{2}{|r|}{ Outer lobe } & \multicolumn{2}{|c|}{ Lamellae sets } & \multirow{2}{*}{$\begin{array}{l}\text { Site of } \\
\text { observation }\end{array}$} & \multirow{2}{*}{$\begin{array}{l}\text { Lobe } \\
\text { scheme }\end{array}$} \\
\hline & & & & Major lamellae & Minor lamellae & & \\
\hline \multirow[b]{2}{*}{$\begin{array}{l}\text { Morphotype } \\
1\end{array}$} & \multirow[b]{2}{*}{$\begin{array}{l}\text { Skirt-like } \\
\text { ("S") } \\
\text { studied specimens } \\
\qquad 14\end{array}$} & \multicolumn{2}{|r|}{ Major interspaces (MI) } & \multirow{2}{*}{\multicolumn{2}{|c|}{$\begin{array}{l}\text { Thickness: } 0.5-1 \mathrm{~mm} \\
\text { Longth: }>20 \mathrm{~cm} \\
\text { Shape: J-shaped } \\
\text { infill: planktonic foramininifera, } \\
\text { calcisphera, inoceramid, and quartz }\end{array}$}} & \multirow[b]{2}{*}{ Zirba } & \\
\hline & & 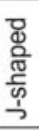 & $\begin{array}{l}\text { Width: }<0.5 \mathrm{~mm} \\
\text { Longth: }>20 \mathrm{~cm} \\
\text { Form: J-shaped } \\
\text { Infill: very fine mud and silt }\end{array}$ & & & & \\
\hline \multirow{5}{*}{$\begin{array}{l}\text { Morphotype } \\
2\end{array}$} & \multirow{5}{*}{$\begin{array}{l}\text { Tongue-like } \\
\text { ("T") } \\
\text { studied specimens } \\
\quad 38\end{array}$} & \multicolumn{2}{|r|}{ Major tubes (MT) } & \multirow{2}{*}{\multicolumn{2}{|c|}{$\begin{array}{l}\text { Internal lamellae (Li) } \\
\text { Thickness: } 0.3-1 \mathrm{~mm} \\
\text { Longth: } 2 \mathrm{~cm} \\
\text { Shape: Concave-up } \\
\text { Infill: Calcisphera with } \\
\text { fecal pellets }\end{array}$}} & \multirow[b]{2}{*}{ Oued Zitoun } & \\
\hline & & \multirow{2}{*}{ 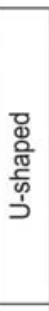 } & $\begin{array}{l}\quad \text { TU-1 } \\
\text { Width: } 5-20 \mathrm{~mm} \\
\text { Longth: more than } 15 \mathrm{~cm} \\
\text { Form: U-shaped } \\
\text { Infill: very fine mud } \\
\text { and silt with pyrite }\end{array}$ & & & & \\
\hline & & & $\begin{array}{l}\text { TU-2 } \\
\text { Width: } 3-10 \mathrm{~mm} \\
\text { Longth: more than } 15 \mathrm{~cm} \\
\text { Form: U-shaped } \\
\text { Infill: rust-colored coating }\end{array}$ & \multicolumn{2}{|c|}{$\begin{array}{l}\text { Internal lamellae (Li) } \\
\text { Thickness: }<0.5 \mathrm{~mm} \\
\text { Longth: } 4 \mathrm{~cm} \\
\text { Shape: Concave } \\
\text { Infill: Calcisphera with } \\
\text { fecal pellets }\end{array}$} & Zirba & \\
\hline & & \multirow{2}{*}{ 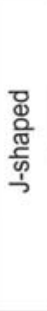 } & $\begin{array}{l}\quad \text { TJ-1 } \\
\text { Width: } 5-12 \mathrm{~mm} \\
\text { Longth: more than } 17 \mathrm{~cm} \\
\text { Shape: U-shaped? } \\
\text { Infill: pelleted materials }\end{array}$ & $\begin{array}{l}\text { Major lamellae (LM) } \\
\text { Thickness: } 1 \mathrm{~cm} \\
\text { Longth: underterminated; } \\
\text { Shape: underterminated } \\
\text { Infill: mud with pellets }\end{array}$ & $\begin{array}{l}\text { Minor lamellae (Lm) } \\
\text { Thickness: } 0.5-1 \mathrm{~mm} \\
\text { Longth: } 0.5-3 \mathrm{~cm} \\
\text { Shape: concave } \\
\text { and sigmoidal } \\
\text { Infill: pelleted material } \\
\end{array}$ & \multirow[b]{2}{*}{$\begin{array}{l}\text { Oued } \\
\text { EI Melah }\end{array}$} & \\
\hline & & & $\begin{array}{l}\quad \text { TJ-2 } \\
\text { Width: } 1-4 \mathrm{~mm} \\
\text { Longth: more than } 4 \mathrm{~cm} \\
\text { Shape: J-shaped in } \\
\text { one side } \\
\text { Infill: coarse mud with } \\
\text { iron-coating }\end{array}$ & & $\begin{array}{l}\text { Minor lamellae }(\mathrm{Lm}) \\
\text { Thickness: }<0.5 \mathrm{~mm} \\
\text { Longth: } 2-6 \mathrm{~cm} \\
\text { Shape: concave } \\
\text { to planar } \\
\text { Infill: pelleted material }\end{array}$ & & \\
\hline
\end{tabular}

Table 1. Basic lobe characteristics of the of the studied Zoophycos morphotypes. 


\subsubsection{Skirt-like morphotypes}

The skirt-like "S"-morphotypes are composed of several, at least 3 stacked lobes connected to a central oblique shaft (Figure 8A, B). The uppermost lobe is commonly complete, while it overlaps the previous ones and deviates by $\sim 90^{\circ}$ from the orientation of the lower lobe. These features imply that the observed burrows were constructed upward and counterclockwise. Fourteen specimens have been observed in the Zirba section. The basic lobe is narrow near the shaft and widens downward constituting a skirt-like morphology (Figure 8C, D). The lobe is in average about $10 \mathrm{~cm}$ wide.
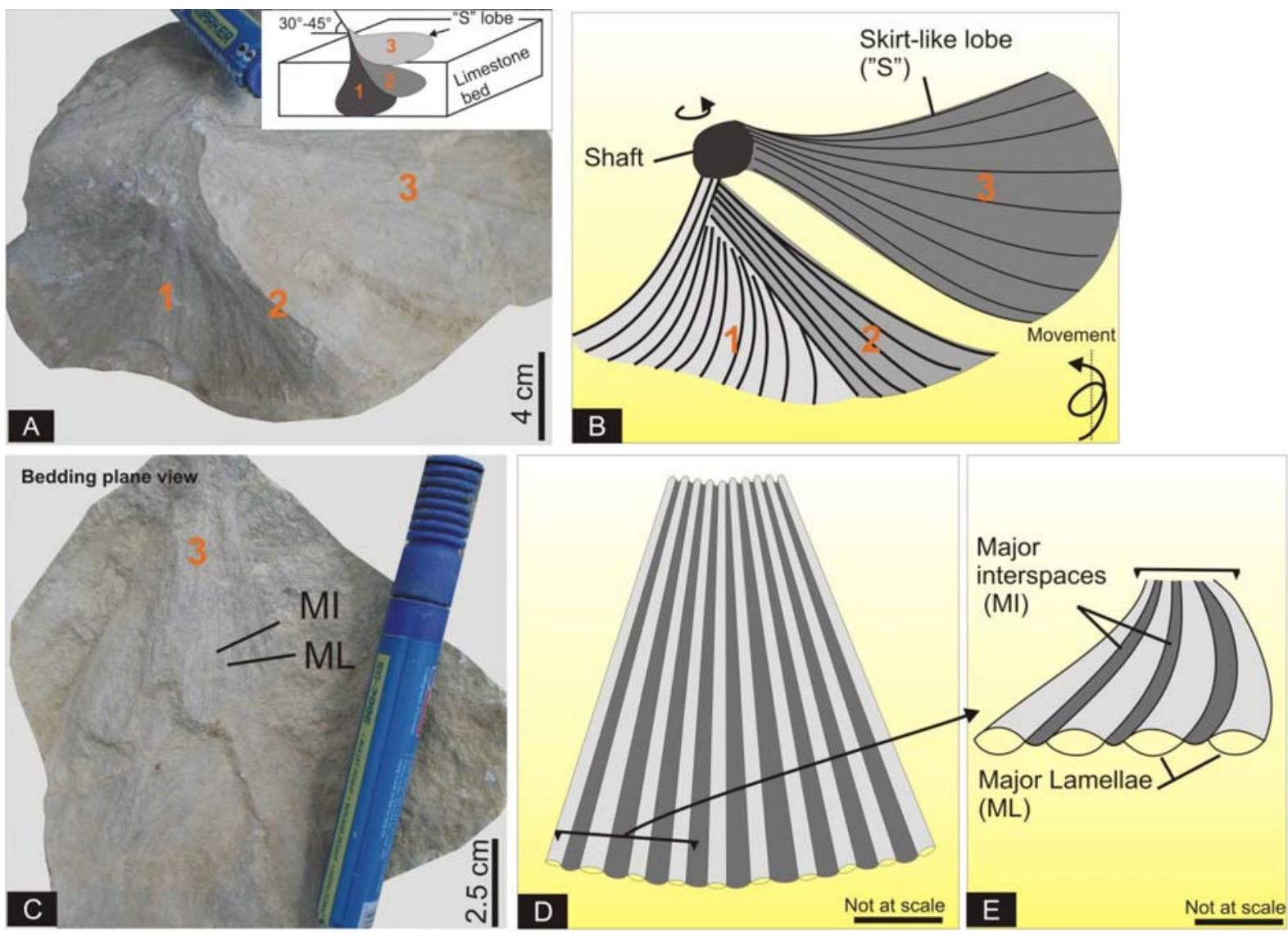

Figure 8. Zoophycos - skirt-like morphotype. (A) Field photograph (inset - 3D scheme) and (B) line drawing showing helicoidal, lobate Zoophycos composed at least of three skirt-like lobes, fixed to shaft. (C) Field photograph and (D) line drawing showing the main structural elements of the skirt-like basic lobe.

The basic lobe consists of concave, $0.5-3 \mathrm{~cm}$ wide J-shaped radiating grooves separated by $0.5-2 \mathrm{~mm}$ thick convex tunnel-like ridges both extending down from the shaft (Figure 8E). The J-shaped concave radiating grooves represent the major interspaces (MI) and the convex tunnel-like ridges major lamellae (ML). This morphotype does not display a marginal tube. Major lamellae and major interspaces contain relatively well-sorted fill material rich in calcisphera and non-keeled pelagic foraminifera tests and occasionally inoceramid prisms and detrital quartz (Figure 9). The major lamellae are richer in calcisiltitic sediment than the rather flat major interspaces. Relatively coarse grains such as keeled planktonic foraminifera tests are present always outside, but close to the major lamellae suggesting that they were pushed aside when the major lamellae were formed. 


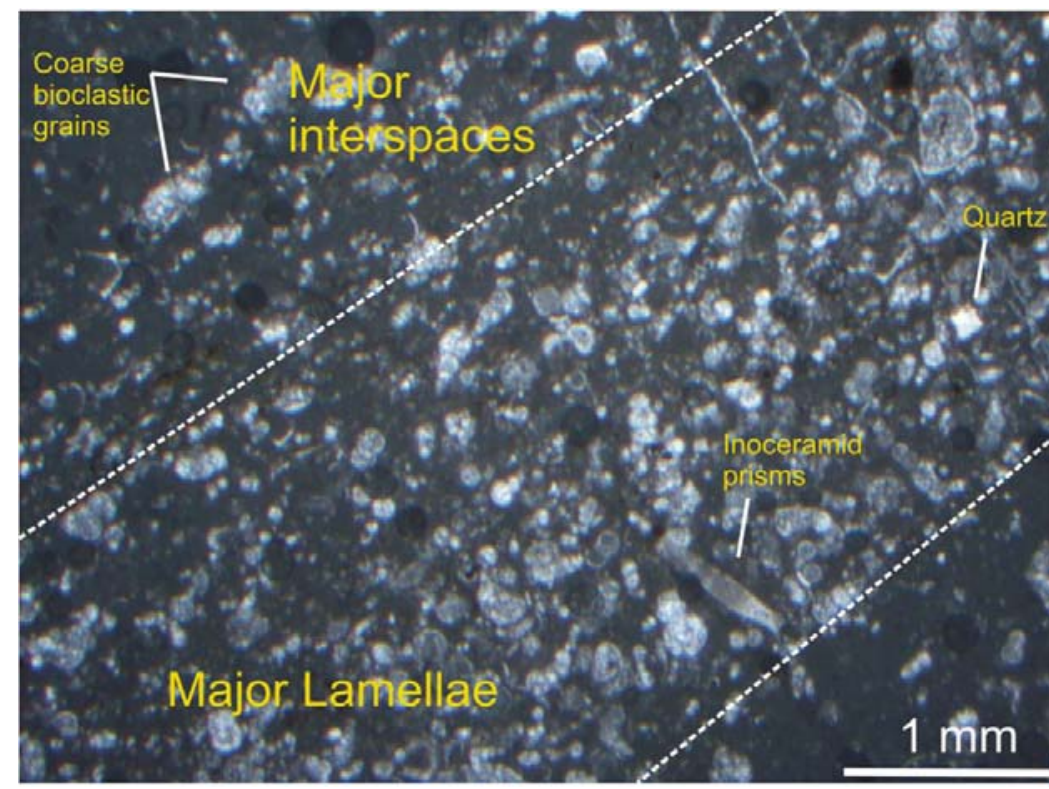

Skirt-like lobe

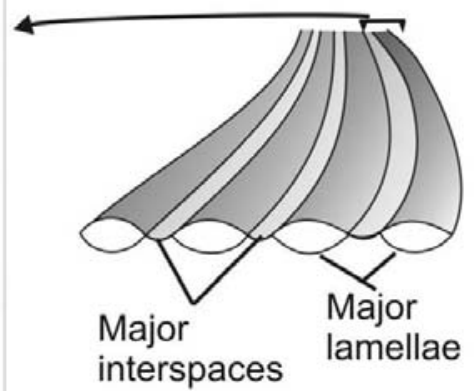

Figure 9. Petrographic characteristics of the skirt-like lobe showing sediment-rich major lamellae and mud-rich major interspaces. Note that some coarser grains such as keeled foraminifer tests are pushed out the major lamellae.

\subsubsection{Tongue-like morphotypes}

The tongue-like "T"-morphotypes consist of several tongue-like basic lobes, which very likely are connected to the shaft as suggested by the upward narrowing of the spreite, but unfortunately the shaft itself was not observed. With respect to the shape of the basic lobe, a U-shaped (TU) and a J-shaped (TJ) variety are distinguished (Table 1). In all 3 studied sections, totally 38 tongue-like Zoophycos were found.

The TU Zoophycos are composed of U-shaped basic lobes parallel, oblique or perpendicular to bedding. The basic lobes are in average $17 \mathrm{~cm}$ long and $2-3 \mathrm{~cm}$ wide. They commonly display $0.5-1 \mathrm{~mm}$ wide, U-shaped lamellae bordered by the marginal tube (Figure 10A, B). The marginal tube exhibits either the same composition as the lobes (type-1: TU-1) or a rust-colored coating (type-2: TU-2; Figure 11). Similar iron-coatings are present on other limestone bed surfaces interpreted as firmground or hardground (Belghouthi, Zouari, and Jeddi 2019). Some limestone beds located $\sim 30 \mathrm{~cm}$ above the Zoophycos-bearing layers are bored by sparse Gastrochaenolites. Although Zoophycos was not observed in these beds, the TU-2 traces having rust-colored marginal tubes appear to have been produced in stiffened sediment.

The TJ morphotypes share striking similarities with Zoophycos rhodensis Bromley and Hanken 2003 and hence, are classified as such. Depending on the fill of the marginal tube, a pellet-rich type-1 (TJ-1) and a mud-rich type-2 (TJ-2) are distinguished.

TJ-1 specimens are characterized by $17 \mathrm{~cm}$ long and 2-8 $\mathrm{cm}$ wide basic lobe composed of alternating, $1 \mathrm{~mm}$ thick concave internal lamellae bound by a marginal tube being $5-12 \mathrm{~mm}$ wide (Figure 12A, B). The latter shows pellet-rich fill composed of well rounded, ellipsoidal dark-grey to rust-colored pellets $0.5 \mathrm{~mm}$ in size. These pellets appear to be somehow oriented and preferentially scattered. Similar features were interpreted as evidence of multiple reworking by the producers (Knaust 2013). At one side of the lobe, the marginal tube twists in its upper part and thins apparently downward and thus, suggests to be J-shaped. The twisted part is defined as an "interlobe" zone that is separated from the internal lamellae by a $1 \mathrm{~cm}$ thick, V-shaped zone containing abundant rust-colored pellets (Figure 12A, B). The interlobe 

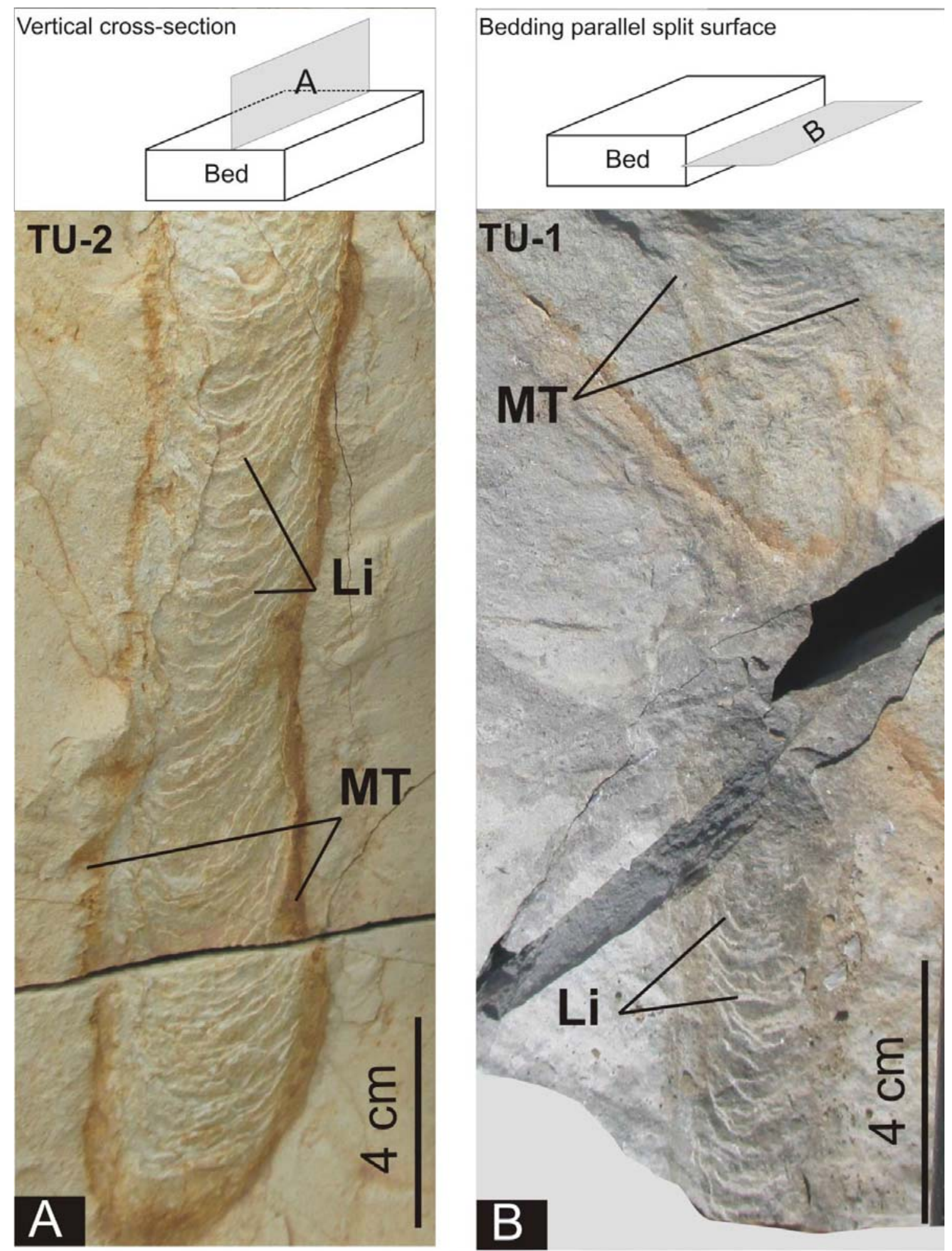

\section{Li: Internal lamellae; MT: Marginal tube}

Figure 10. Zoophycos tongue-like morphotype. A-B, tongue-like basic lobes composed of internal lamellae outlined by marginal tube. Note that the marginal tube (MT) of the TU-2 morphotype is marked by rust-colored coatings. 


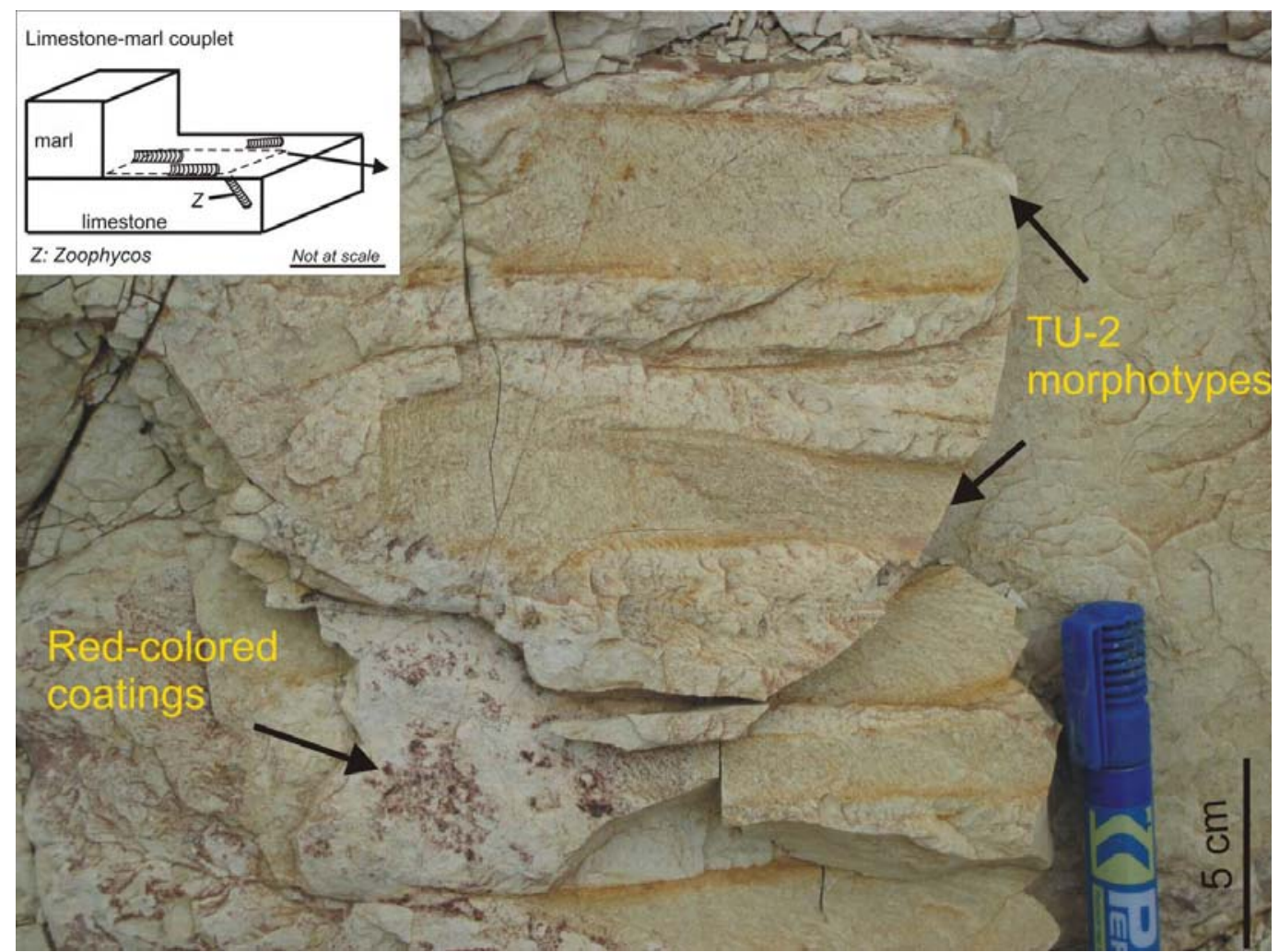

Figure 11. Zoophycos TU-2 morphotypes with rust-colored marginal tube located in limestone bedding surface marked by red-marron iron-coating interpreted as condensed level.

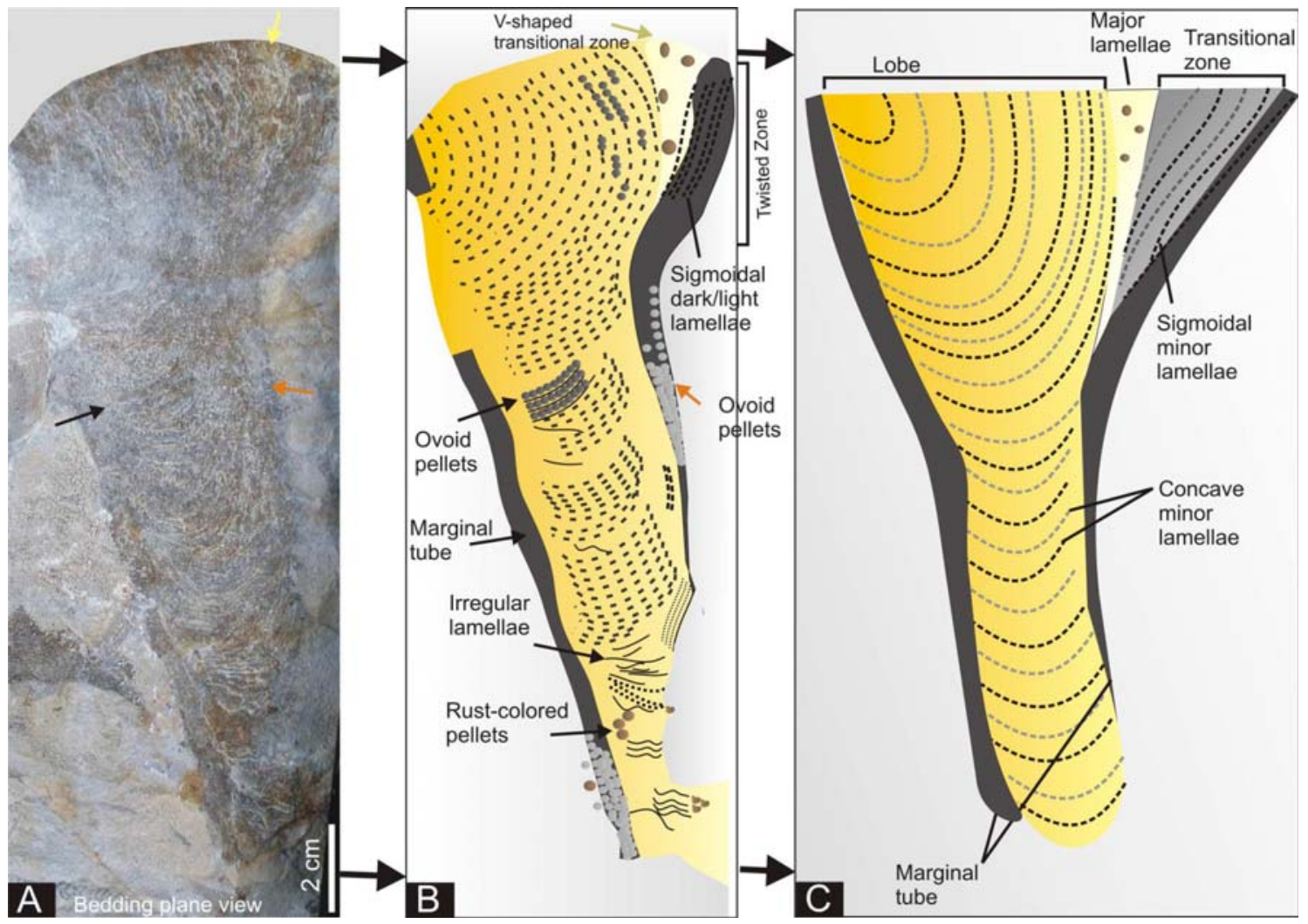

Figure 12. TJ-1 Zoophycos rhodensis morphotype. (A) Field photograph, (B) line drawing and (C) schematic interpretations of TJ-1 basic lobe. 


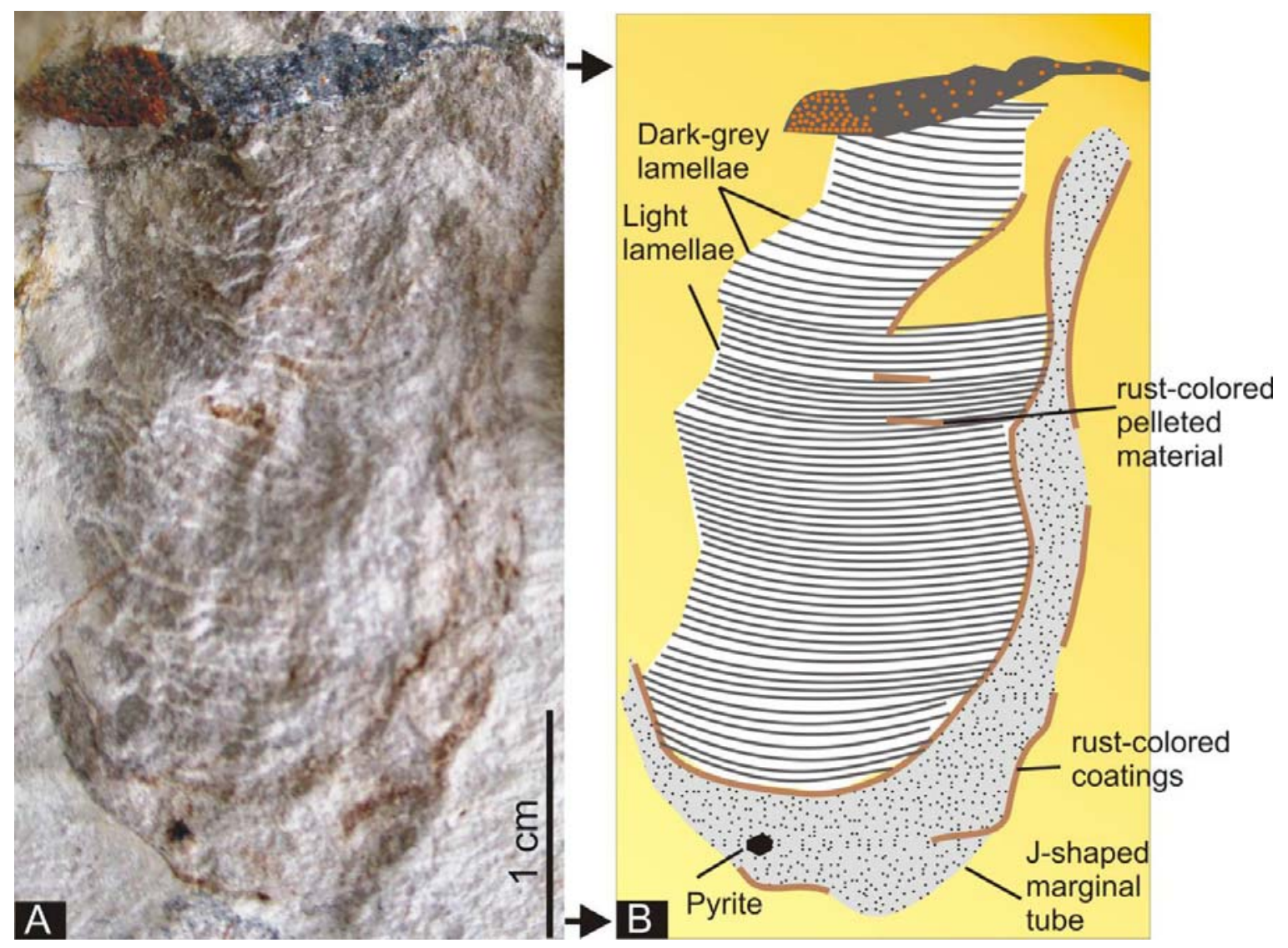

Figure 13. TJ-2 Zoophycos rhodensis morphotype. (A) Field photograph and (B) line drawing of basic lobe.

zone is marked by sigmoidal, alternating dark and light lamellae of similar thickness as the internal lamellae. In comparison to Z. rhodensis, the dark and light lamellae are equivalent to minor lamellae, while the structureless zone separating the lobe from the interlobe zone may represent a major lamellae (Figure 12C). The interlobe zone of the studied specimens matches the characteristics of the so-called "skirt-like zone" of Bromley and Hanken (2003). The dark and light minor lamellae of the Z $\mathrm{Z}$. rhodensis are commonly discontinuous and appear somewhat "coalescent". The dark minor lamellae are dark-grey and contain abundant ellipsoidal, dark-colored and scattered rust-colored pellets $0.5 \mathrm{~mm}$ in size. The major lamellae are structureless and commonly contain scattered rust-colored pellets.

The TJ-2 specimens have a $>4 \mathrm{~cm}$ long and $2-6 \mathrm{~mm}$ wide basic lobe, commonly composed of dark-grey internal lamellae that are bound at one side by a J-shaped marginal tube (Figure 13A, B). The internal lamellae are planar and dark-grey in color. They contain fine-grained mud and some rust-colored pellets. The $1-4 \mathrm{~mm}$ wide marginal tube is commonly filled with mud and occasionally pyrite and exhibits rust-colored inner walls.

In cross-section, the tongue-like lobes appear as bands of alternating crescent-shaped, dark and light menisci containing pellets (Figure 14A). The dark menisci are thicker than the light ones or nearly equal. The menisci are equivalent to the minor lamellae. In thin-section, the dark menisci appear to be enriched in well-sorted, fine-grained calcisiltite dominated by oligosteginids/calcisphera compared with the light menisci (Figure 14B). Coarse bioclasts like keeled foraminifera, however, are pushed aside of the lamellae. The dark menisci, particularly in TJ-2 specimens contain pyrite framboids as seen in SEM (Figure 14C). 

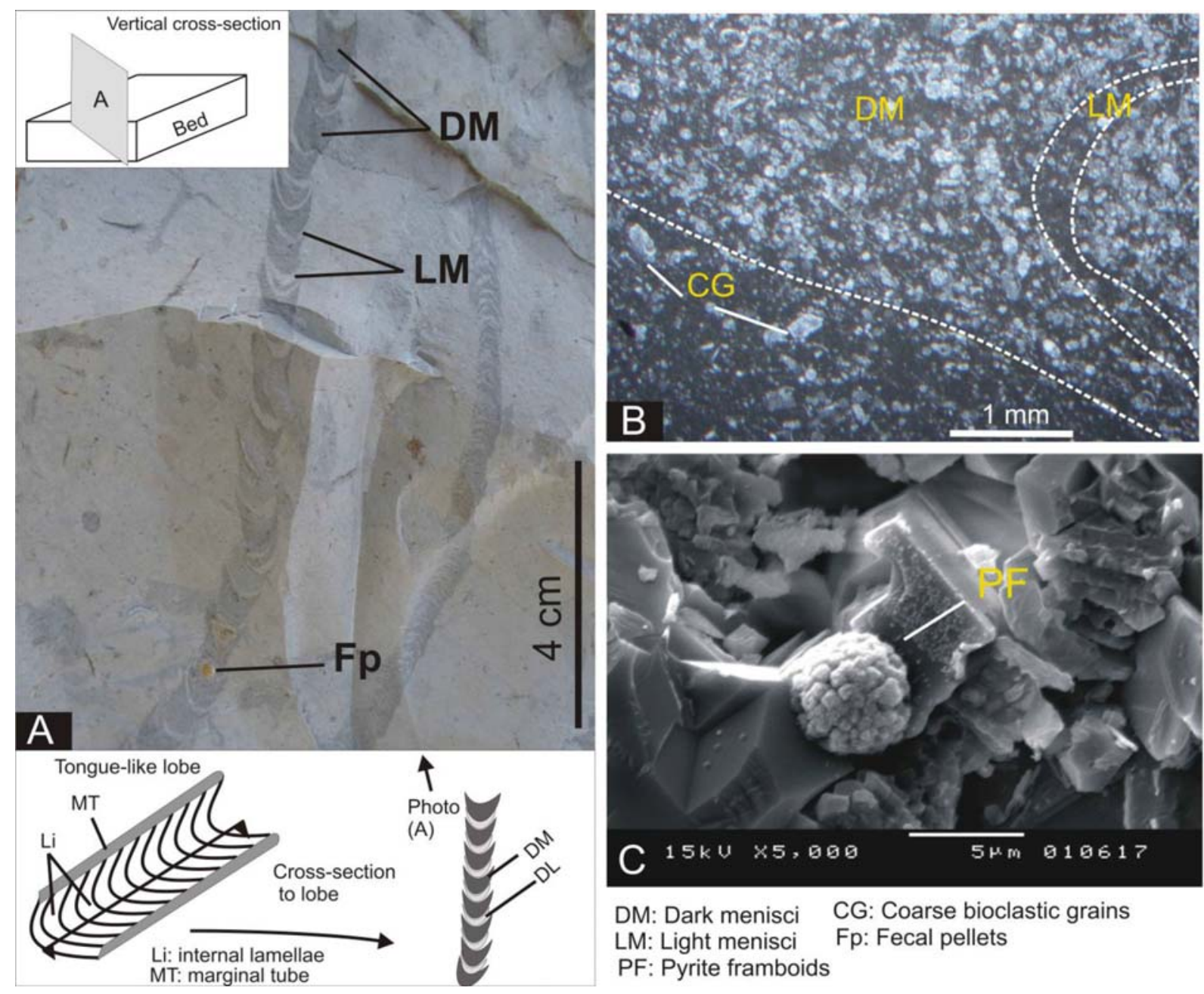

DM: Dark menisci CG: Coarse bioclastic grains

LM: Light menisci Fp: Fecal pellets

PF: Pyrite framboids

Figure 14. Petrographic characteristics of tongue-like Zoophycos morphotypes. (A) Vertical crosssection to lobe of tongue-like morphotypes showing alternating of dark/light containing fecal pellets. (B) Thin-section view of the dark/light menisci showing alternation of sediment-rich dark menisci and mud-rich light menisci. The sediment is mainly composed of oligosteginid/calcisphera. Note that relatively coarse grains are ejected out the menisci. (C) SEM view of the dark menisci showing pyrite framboids $(\mathrm{PF})$, interpreted as sign of bacterial culture.

\subsection{Construction of basic lobes}

The basic lobes of S- and T-type Zoophycos differ in morphology, infill, and internal structures and, therefore, they document different behavioral programs.

\subsubsection{Skirt-like morphotypes}

The skirt-like lobes were produced in several steps. First, the producer burrowed down into the substrate and constructed a steep shaft resembling Skolithos (Figure 15A, stage a). It continues in a decreasingly inclined, finally horizontal tube (Figure 15A, stage b). Then the producer started to shift the tube laterally and to form a spreite; during excavation, sediment was pushed aside, but the majority of the material was transported out of the burrow because the deposits around the spreite are not clearly distorted (Wetzel and Werner 1980; Bromley 1991). Furthermore the producer started to collect organic-rich material on the seafloor and to transfer and deposit it in the burrow while moving upward and downward through the same J- 
shaped major tunnel. Finally, the tunnel was backfilled, beginning distally and finishing proximally near the shaft (Figure 15A, stage c). The fill constitutes major lamellae. When the animal reached the proximal side, the producer started to construct a new tunnel adjacent to, but also partly overlapping the just formed major lamellae, and so forth (Figure 15A, stages d, $\mathrm{e}, \mathrm{f}, \mathrm{g})$.

This behavioral program resembles that deduced for Zoophycos found in Holocene continental slope deposits off Portugal (Löwemark and Schäfer 2003). However, the morphology of major lamellae and tunnels and hence, the way of construction show some differences. The studied Zoophycos burrows are composed of J-shaped major lamellae and the lobes are successively and, thus, discontinuously formed around a central shaft while the Holocene specimens display U-shaped major lamellae and represent a rather continuously produced helicoidally coiled spreite structure (Löwemark and Schäfer 2003, Figure 12). However, the usage of a J- or U-shaped causative tube may depend on the oxygen content of the bottom water and/or host sediment and, therefore, may represent only an 'environmental variant' of Zoophycos (Wetzel and Werner 1980).

\subsubsection{Tongue-like morphotypes}

The tongue-like basic lobe was also constructed in several steps (Figure 15B; see, for instance, Zhang, Shi, et al. 2015). The T Zoophycos are composed of lamellae sets bordered by a marginal tube and, hence, document protrusive formation of the spreite, but the construction mode is different for the TU and TJ types.

The TU specimens were formed while the producer moved to and for through the U-shaped causative (marginal) tube (Figure 15B, stage a). Undisturbed host sediment adjacent to the spreite documents that the fill was placed in a pre-existing cavity while the original sediment was conveyed to the surface (see Bromley 1991). The fill is enriched in organic matter and plankton tests collected from the seafloor (Figure 15B, stage b). The causative (marginal) tube was kept open to facilitate the up-and-down movement of the producer and supply of respiration water. After a tunnel was completely filled ( $1 / 4$ lamellae), the producer excavated a new one, and so on (Figure 15B, stages c, d). The resultant structure represents a protrusive U-shaped, tongue-like spreite lobe (Figure 15B, stage e). The next lobe was formed aside of the previous.

The TJ morphotypes are similar to Zoophycos rhodensis. For Z. rhodensis, the major lamellae appear to extend radially from the shaft or apex to the lower margin of the lobe. The minor lamellae are bound at both sides by major lamellae (Bromley and Hanken 2003, Figure 4). This configuration matches that of TJ-1 and TJ-2 specimens and they are, thus, suggested to have been formed in the same protrusive way (Figure 15C, stages a, b, c). The lower part of TJ-2 lobe displays a J-shaped marginal tube surrounding half of the lobe while the distal part of the marginal tube was backfilled (Figure 15C, stage d). The twisted upper part of the marginal tube could have acted as an exit and/or turning/bending area during construction of the transition zone that is bound by major lamellae and, hence, the animal repeatedly passed through. The construction of a new lobe started when the distance between burrow entrance and distal part of a spreite became too long, maybe given by the body length of the producer (Figure 15C, stage d, e). 


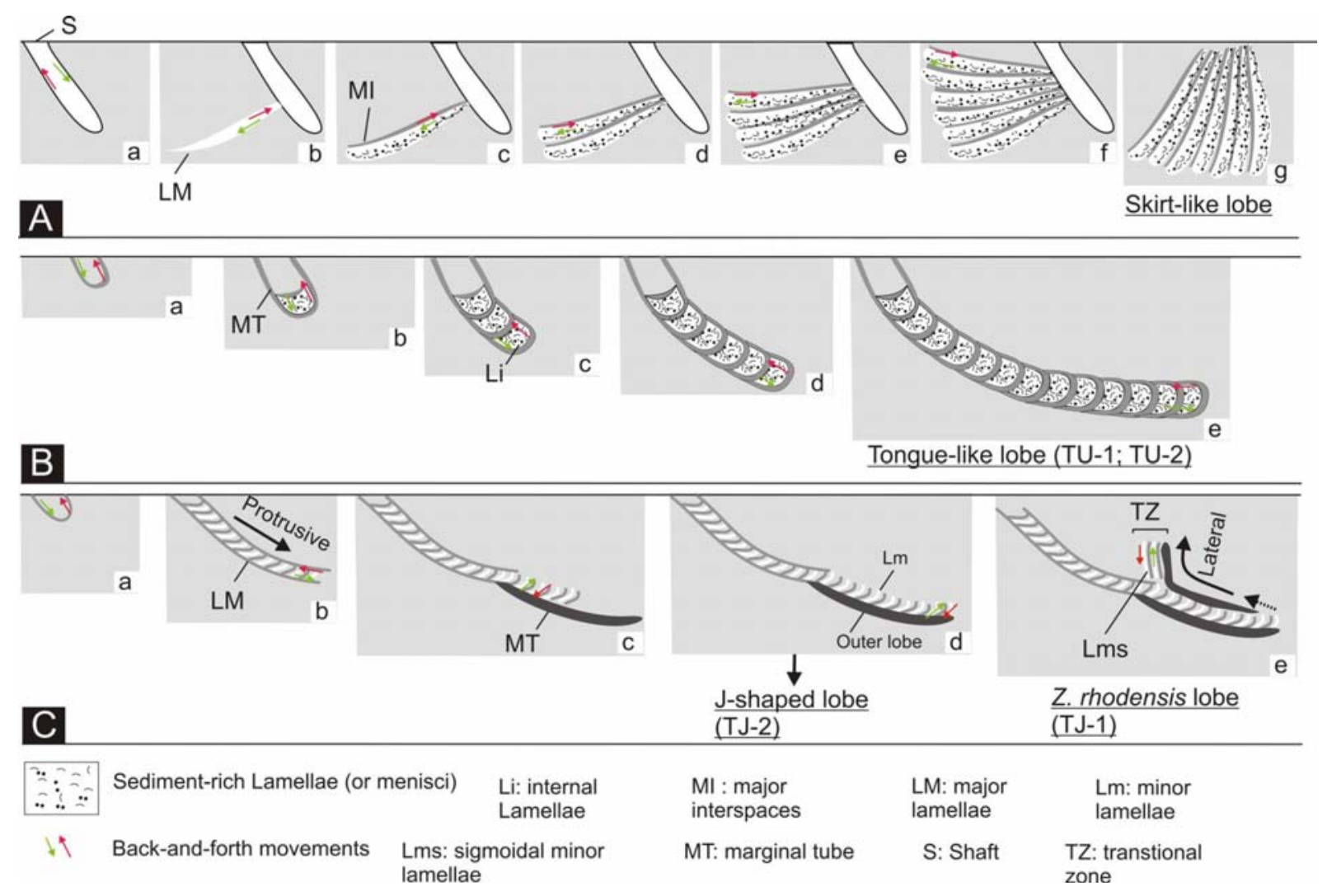

Figure 15. Construction of basic lobe of the studied Zoophycos morphotypes. (A) Skirt-like basic lobe. (B) TU basic lobe. (C) TJ basic lobe.

The Zoophycos producers constructed and used the tongue-like spreite as cache (e.g., Bromley 1991): They excavated a wide cavity to store organic-rich material and to enhance microbial activity therein while located deep below the surface within a geochemical suitable zone, very likely at or below the redox potential discontinuity. The animal transported sediment upward and downward through the major lamellae when they represented temporary tunnels and stored organic-rich material collected on the seafloor in the minor lamellae that acted as cache (e.g., Olivero and Gaillard 2007). The fill consists of fecal pellets that very likely acted as substrate for microbes. The microbial metabolic products represent a potential food source when, for instance, priming resulted in the supply of organic compounds in a rather short while (cf. Aller and Cochran 2019).

\subsection{Ethological interpretation}

All Zoophycos specimens share some common features. (i) The traces occur in sediment containing $0.1-0.4 \% \mathrm{C}_{\text {org. }}$. Although the organic content is not too high, at least the ruststained deposits and those still containing pyrite have had an anoxic pore water and substantiate that the cache was constructed within anoxic deposits. (ii) The lobes extend in various directions and are oriented at different angles resulting in complex helicoidal patterns that contradict a preferential distribution of organic matter. These facts suggest that the studied Zoophycos do not record a simple deposit-feeding strategy of their producers (Seilacher 1967; 2007) rather than a complex behavior adapted to variable environmental conditions (e.g., Rodríguez-Tovar, Löwemark, and Pardo-Igúzquiza 2011; Wetzel, Tjallingii, and Wiesner 2011; Wetzel and Uchman 2012; Küssner et al. 2018). 
The skirt-like morphotype resembles Echinospira pauciradiata Girotti (1970). The major lamellae contain sorted and relatively coarse sediment that differs from the surrounding host rock. This material was presumably collected on the seafloor and conveyed into the burrow. The major lamellae contain mainly fine sediment, little quartz, inoceramid prisms and some fecal pellets. Given the animal transported this material in its gut (e.g., Bromley 1991), the transfer of indigestible grains such as quartz into the cache is useless. Therefore, the Zoophycos producer did not collect nutritious material very selectively, but rather random and fast although it has the capability to sort sediment as evidenced by the coarse grains sorted out and pushed aside along the spreite (see above). Random and quick ingestion is interpreted to imply either the fear of predators or the competition for limited food probably being available only for a short time (see below). The downward transfer of particles from the surface into the burrow matches the cesspit model as an animal feeds on the surface and excretes fecal pellets in an orderly way subsurface (Kotake 1989). The studied Zoophycos contain only some fecal pellets, but even if they are nearly absent, the material probably has passed the gut as observed off NW Africa while within one spreite, the fill is changing from pelleted to homogeneous (Wetzel and Werner 1980, Figure 9). In addition, the absence of pellets can result from significant sediment reworking (Miller and d'Alberto 2001).

The morphotypes TU-1 and TU-2 have a protrusive spreite and a marginal tube binding the internal lamellae. Fecal pellets as well as the obvious difference in composition between the dark menisci and surrounding host rock suggest that material was transferred from above and excreted under the seafloor. These features are in favor of the cesspit or cache model (Kotake 1989; Bromley 1991). The rust-staining of TU-2 specimens is interpreted to indicate the former presence of iron sulfides that became oxidized later (maybe during weathering). A Ushaped marginal tube is suitable to pump efficiently respiration water if bottom water is low in oxygen or the sediment strongly anoxic (Wetzel and Werner 1980). Furthermore, "cultivated" or "gardened" microbes would benefit from ventilation because a steep geochemical gradient develops between oxygenated respiration water and organic-rich spreite fill (e.g., Meysman et al. 2010). The presence of pyrite framboids in the lobes has been interpreted to indicate (the former presence of) microbial colonies (Gong et al. 2008; Zhang, Shi, et al. 2015). Furthermore, the TU-2 specimens having rust-stained marginal tubes occur in beds that formed during times of low sedimentation. Around storm-wave base where the Zoophycos producers lived the supply of nutritious material fluctuated strongly due to hydraulic conditions. Construction of a cache and stimulation of microbial activity therein represent a good adaptation to such an environment. Furthermore, in Late Quaternary to Holocene hemipelagic sediments, Zoophycos has been found to be rather abundant when sedimentation rates slowed down (Küssner et al. 2018). Similarly, Zoophycos preferably occurs in stiff to firm Mesozoic marls and marly limestones that formed when sedimentation rate was low (Olivero 1996).

In modern environments, the delivery of nutritious material to the seafloor is mainly seasonal (e.g., Lutz et al. 2007) and currents may affect it in addition. Seasonality of organic flux to seafloor probably stimulated the Zoophycos producers to store organic material inside their burrows to be utilized during times of restricted benthic food availability (cache model; e.g., Jumars et al. 1990; Bromley 1991; Dorador, Wetzel, and Rodríguez-Tovar 2016). The cache model supposes that Zoophycos producers recycle the previously stored material during scanty conditions. Under such conditions, the Zoophycos producers may shift - in addition to gardening activity because microbial activity can provide nutritious material via priming/ 
secondary production (e.g., Middelburg 2018). Thus, storing organic material in a cache below seafloor can be supplemented by gardening.

The producers of $Z$. rhodensis were interpreted to follow a complex behavior while depositfeeding, gardening, stimulating chemosymbiosis and taking advantage thereof (Bromley and Hanken 2003). In this context, the repeatedly reworked transitional zone appears to be related to deep-deposit utilization and stimulated microbial activity, while the lobes were domains of gardening and chemosymbiosis. In Z. rhodensis TJ-1 specimens, outer lobes and minor lamellae contain pelleted material showing signs of repeated reworking such as variations in size and morphology of pellets and preferential orientation within lamellae and major tube (e.g., Knaust 2013). These characteristics are in favor of a combined cache and cesspit model for the TJ-1 morphotype while enriched in planktonic material and fecal pellets, respectively. In addition, some scattered, morphologically similar fecal pellets exhibit a rust-colored coating. They occur along the inner wall of the marginal tube and inside the major lamellae. Very likely these pellets were enriched in organic matter. The rust coating implies the previous presence of iron sulfides and, hence, sulfate-reducing microbes. If so, gardening behavior is also likely for the Z. rhodensis TJ-1 producer.

The construction of the outer lobe and the transitional zone enlarges significantly the space to store material. The presence of a transitional zone in Z. rhodensis TJ-1 is hypothetical except the twisted part of the outer lobe that is composed of alternating sigmoidal pelleted and unpelleted minor lamellae. They display the same composition and characteristics as the minor lamellae of the outer lobes and, thus, they were formed in lateral continuity within them. The twisted part of the outer lobe is interpreted to increase the volume of interstitial sulfidic pore water collectable from the adjacent long lobe (Bromley and Hanken 2003).

In Z. rhodensis TJ-2 specimens, the lobes are composed of alternating pelleted and unpelleted material that shows some signs of reworking. The fill of the marginal tube does not contain pellets as in TJ-1 Z. rhodensis specimens. In contrast, a thin rust-colored film marks the internal wall of the marginal tube. Such a coating associated with pyrite is also seen separating the minor lamellae. The coating consists of small rust-colored pellets embedded in micrite. The coating, therefore, probably has had pyrite as precursor that became oxidized during weathering. The outer lobe is J-shaped and contains relatively coarse unpelleted sediment. The absence of pellets suggests that this material was not designated for the later exploitation: If the outer lobes acted as sulfide collectors (Bromley, Ekdale, and Asgaard 1999), the high permeability of the coarse sediment fill facilitates efficient 'sulfide mining' and microbial gardening (Bromley and Hanken 2003). Thus, chemosymbiotic activity is suggested for the producers of TJ-2 Z. rhodensis specimens.

\section{Discussion}

Zoophycos occurs in shallow to deep marine, mainly muddy environments episodically affected by currents as it is characteristic of the Zoophycos ichnofacies (Seilacher 1967; MacEachern et al. 2012). The preference of shallow-water Zoophycos producers to exploit habitats influenced by episodic currents is interpreted as an opportunistic behavior while responding to nutritious material delivered from high-productivity areas. In the study area, Zoophycos was not observed in turbidites that are present below the ZU unit. Therefore, the Zoophycos producers tend to prefer a habitat affected by storms that may deliver recurrently additional benthic food from shallow-marine areas where primary productivity is commonly 
enhanced (e.g., Antoine, André, and Morel 1996). The transfer of benthic food in a carbonateramp setting is likely to be climatically-controlled by monsoon or upwelling as observed in modern environments (Wetzel and Werner 1980; Löwemark and Schäfer 2003; RodríguezTovar, Löwemark, and Pardo-Igúzquiza 2011; Wetzel, Tjallingii, and Wiesner 2011). In the ZU unit, sedimentary structures imply sediment transport by surge-like storm-induced currents to deeper settings. Furthermore, oscillation ripples document activity of waves that could wash out fine-grained material including organic particles and keep them in suspension until deeper tranquil environments are reached. The lateral transport of organic-rich fine material was further enhanced by along slope currents documented by the channel-like structures (Figure 7).

The response of Zoophycos producers to the intermittent arrival of nutritious material is complex. Ethological interpretation of the skirt-like and tongue-like Zoophycos morphotypes suggesst an increase in their ethological variety and burrow complexity with respect to food availability that decreases with distance from coast and with the recurrence time of storm events. For instance, the skirt-like specimens occur in a lower ramp setting around stormwave base (Zirba section) and tongue-like TU-1 morphotype on the distal ramp below stormwave base (Oued El Melah section). The latter displays an increased ethological variety including cache and cesspit construction as well as possibly gardening activity while located further offshore in larger distance to the food source. In contrast, TU-2 morphotypes document ethological programs of cesspit and gardening activity while occurring in a slowly accumulated interval.

The morphology of Zoophycos is evidently linked to the sedimentary environment and the Zoophycos producers choose a specific habitat. The Zoophycos producers appear to be particularly adapted to a depositional setting characterized by intermittent environmental conditions shifting between low and high energy and low and high trophic levels. During the end of the Mesozoic, Zoophycos production shifted to deep-marine settings where food availability fluctuates even ore severely. The studied Late Maastrichtian case may represents a step within this trend.

The enhanced abundance of Zoophycos in marls (Oued Zitoun section) implies that the trace fossil producers are adapted to fine-grained deposits. The Zoophycos producers collected organic-rich particles on the surface, stored them subsurface and might have even stimulated microbial activity in the cache by pumping water through the burrow system. This deduction is supported by two petrographic observations on the fill of the spreite: (i) coarse bioclasts, such as keeled foraminifera have been pushed out of the spreite because they are evidently unsuitable. In contrast, enrichment of sorted, fine oligosteginids/calcisphera indicate that the Zoophycos producer collected fine particles on the seafloor. Nonetheless, the selectivity appears to be restricted to grain size and not to nutritious value otherwise indigestible grains like fine quartz would not have been transferred into the burrow.

Most marl deposits are interpreted to have settled from storm-induced currents, except a few cases when marls were transported via channels. The settling of organic detritus out of suspension can take relatively long time and hence, provide rather long-lasting organic supply to the seafloor as indicated by oligosteginids/calcisphera-rich deposits (Arthur, Schlanger, and Jenkins 1987; Luciani and Cobianchi 1999). In a lower-ramp setting, storm and bottom currents may result in low sedimentation rates that foster dewatering of sediments and even development of firmgrounds and hardgrounds. 
The studied Zoophycos occur around storm-wave base and somewhat below and, hence, in much shallower setting than modern ones (Wetzel and Werner 1980; Löwemark and Schäfer 2003; Zhang, Shi, et al. 2015). The complexity of Zoophycos burrow architecture has been found to increase with the shift to deeper environments (Olivero 2003). The observations in the study area match this finding. The behavioral varities of the Zoophycos producers were apparently related to the bathymetric position that affected the distance to the primary food source and the storm-current induced delivery of additional organic-rich material.

\section{Conclusions}

The lower Maastrichtian carbonate deposits of the Mateur-Beja area, northern Tunisian, formed on a storm-dominated ramp and show particular relationships to the occurrence of Zoophycos. Besides seasonal fluctuations of the benthic food supply, episodic transfer of nutritious material from shallow areas to deeper settings by storm-induced waves and currents affected the Zoophycos producers. The abundance of Zoophycos appears to reflect the availability of benthic food. The complexity of Zoophycos with respect to burrow morphology and behavior of their producers increased with distance to primary food sources and the recurrence time of storms delivering supplementary nutritious material. In the most distal position from food sources, Zoophycos producers increased the burrow size (lobes and skirt lobes) in the order to maximize the food in stock designated to be exploited during foodrestricted times. During periods of low sediment accumulation, Zoophycos producers shifted to utilize alternative secondary, microbial-related food sources. The adaptation of Zoophycos producers to settings characterized by fluctuating environmental conditions during Early Maastrichtian times could represent a step of the mysterious shift towards the deep-sea floor as habitat.

\section{Acknowledgements}

The present paper is part of F.B.'s thesis prepared at the University of Carthage, Tunisia. We are grateful to Alfred Uchman and Mohamed Hedi Negra for their comments and suggestions during the early stages of the study. Authors appreciate valuable comments by Ludvig Löwemark, Davide Olivero and Sebastián Richiano that improved earlier versions of the paper considerably.

Disclosure statement

No potential conflict of interest was reported by the author(s).

Funding

ETAP, FSB and CERTE are thanked for providing the financial support to this study. 


\section{References}

Aigner, T. 1982. Calcareous tempestites: Storm-dominated stratification in Upper Muschelkalk limestones (Middle Trias, SW-Germany)." In: Seilacher, A., Einsele, G. (Eds.). Cyclic and Event Stratification, 180-198. Berlin, Heidelberg, New York: Spinger.

Allen, J.R.L. 1984. Sedimentary Structures Their Character and Physical Basis (I+II). Development in Sedimentology 30: $515+615$ p. Amsterdam: Elsevier.

Aller, R.C., Cochran, J.K.. 2019. The critical role of bioturbation for particle dynamics, priming potential, and organic $\mathrm{C}$ remineralization in marine sediments: Local and basin scales. Frontiers in Earth Science 7: 157 (13 p.).

Antoine, D.,André, J.-M., Morel, A. 1996. Oceanic primary production 2. Estimation at global scale from satellite (coastal zone color scanner) chlorophyll. Global Biogeochemical Cycles 10: 57-69.

Arthur, M.A.,Schlanger, S.O., Jenkins, H.C.. 1987. The Cenomanian-Turonian Oceanic Anoxic Event, II. Palaeooceanographic controls of organic-matter production and preservation. In: Brooks, J., Fleet, A.J. (Eds.), Marine Petroleum Source Rocks. Geological Society Special Publication, 26: 401-420.

Basilici, G., Vieira de Luca, P.H., Poiré, D.G. 2012. Hummocky cross-stratification-like structures and combined-flow ripples in the Punta Negra Formation (Lower-Middle Devonian, Argentine Precordillera): A turbiditic deep-water or storm-dominated prodelta inner-shelf system? Sedimentary Geology 267: 73-92.

Belghouthi, F. 2014. Les facies des formations Abiod et El Haria á Mateur: Sédimentologie, environnements de dépôts et intérêt pétrolier. Mémoire de Mastére, Université de Carthage, 150 p.

Belghouthi, F., Zouari, H., Jeddi, R.S. 2019. The Lower Maastrichtian chalk in the Ghezala-Mateur area, northern Tunisian domain: Sedimentary environments and early diagenetic features. Journal of African Earth Sciences 149: 291-306.

Ben Mehrez, F., Kacem, J., Dlala, M. 2009. Late Cretaceous synsedimentary diapirism of Bazina-Sidi Bou Krime Triassic evaporites (northern Tunisia): Geodynamic implications. Comptes Rendus Geoscience 341: 78-84.

Bromley, R.G. 1991. Zoophycos: Strip mine, refuse dump, cache or sewage farm? Lethaia 24: 460462.

Bromley, R.G., Ekdale, A.A., Asgaard, U. 1999. Zoophycos in the Upper Cretaceous Chalk of Danmark and Sweden. Greifswalder Geowissenschaftliche Beiträge 6: 133-142.

Bromley, R.G., Hanken, N.M. 2003. Structure and function of large, lobed Zoophycos, Pliocene of Rhodes, Greece. Palaeogeography, Palaeoclimatology, Palaeoecology 192: 79-100.

Burollet, P.F. 1956. Contribution á l'étude stratigraphique de la Tunisie centrale. Annales des mines et de l'énergie, 18: $350 \mathrm{p}$.

Chaabani, F. 1994. Variations sédimentaire sous contrôle tectonique durant le Sénonian supérieur au niveau de la Passe de Chemsi (Tunisie méridionale): Cadre océanographique et implications paléogeographiques. In: Proceedings 4th Tunisian Petroleum Exploration Conference, 7: 443457. Tunis: Entreprise Tunisienne d'Activités Pétroliéres.

Dlala, M. 2002. Les manifestations tectono-sédimentaires d'âge Campanien-Maastrichtien en Tunisie: Implications sur l'évolution géodynamique de la marge Nord-Africaine. Comptes Rendus Geoscience 334: 135-140. 
Dorador, J., Wetzel, A., Rodríguez-Tovar, F.J. 2016. Zoophycos in deep-sea sediments indicates high and seasonal primary productivity: Ichnology as a proxy in palaeoceanography during glacialinterglacial vriations. Terra Nova 28: 323-328.

Dumas, S., Arnott, R.W.C. 2006. Origin of hummocky and swaley cross-stratification - the controlling influence of unidirectional current strength and aggradation rate. Geology 34: 10731076 .

Dumas, S., Arnott, R.W.C., Southard, J.B. 2005. Experiments on oscillatory-flow and combined-flow bed forms: Implications for interpreting parts of the shallow-marine sedimentary record. Journal of Sedimentary Research 75: 501-513.

Ekdale, A.A., Lewis, D.W. 1991. The New Zealand Zoophycos revisited: Morphology, ethology, and paleoecology. Ichnos 1: 183-194.

Gaillard, C., Olivero, D. 1993. Interprétation paléoécologique nouvelle de Zoophycos Massalongo, 1855. Comptes Rendus de l'Académie des Sciences. Série 2, Mécanique, Physique, Chimie, Sciences de lunivers, Sciences de la Terre 316: 823-830.

Girotti, O. 1970. Echinospira pauciradiata gn, sp. n., ichnofossil from the Serravallian-Tortonian of Ascoli Piceno (Central Italy). Geologica Romana 9: 59-62.

Gong, Y.-M., G. R. Shi, G.R., Weldon, E.A., Du, Y.S., Xu, R. 2008. Pyrite framboids interpreted as microbial colonies within the Permian Zoophycos spreiten from southeastern Australia. Geological Magazine 145: 95-103.

Harms, J.C. 1975. Depositional Environments as Interpreted from Primary Sedimentary Structures and Stratification Sequences. Society of Economic Paleontologists and Mineralogists Short Course Notes 2: $161 \mathrm{p}$.

Jumars, P.A., Mayer, L.M., Deming, J.W., Baross, J.A., Wheatcroft, R.A. 1990. Deep-sea depositfeeding strategies suggested by environmental and feeding constraints. Philosophical Transactions of the Royal Society London A331 (1616): 85-101.

Kneller, B. C. 1995. Beyond the turbidite paradigm: Physical models for deposition of turbidites and their implications for reservoir prediction. In: Hartley, J., Prosser, D.J. (Eds.), Characterization of Deep Marine Clastic Systems. Geological Society Special Publication 94: 31-49.

Knaust, D. 2013. The ichnogenus Rhizocorallium: Classification, trace makers, palaeoenvironments and evolution. Earth-Science Reviews 126: 1-47.

Kotake, N. 1989. Paleoecology of the Zoophycos producers. Lethaia 22: 327-341.

Kujawski, H. 1969. Contribution à l'étude géologique de la région des Hédil et du Bejaoua Oriental. Annales des mines et de l'énergie, 24. 282 p.

Küssner, K., Sarnthein, M., Lamy, F., Tiedemann, R. 2018. High-resolution radiocarbon records trace episodes of Zoophycos burrowing. Marine Geology 403: 48-56.

Löwemark, L., Schäfer, P. 2003. Ethological implications from a detailed X-ray radiograph and ${ }^{14} \mathrm{C}$ study of the modern deep-sea Zoophycos. Palaeogeography, Palaeoclimatology, Palaeoecology 192: $101-121$.

Löwemark, L., Schönfeld, J., Werner, F., Schäfer, P. 2004. Trace fossils as a paleoceanographic tool: Evidence from Late Quaternary sediments of the southwestern Iberian Margin. Marine Geology 204: $27-41$.

Löwemark, L. 2015. Testing ethological hypotheses of the trace fossil Zoophycos based on Quaternary material from the Greenland and Norwegian seas. Palaeogeography, Palaeoclimatology, Palaeoecology 425: 1-13. 
Luciani, V., Cobianchi, M. 1999. The Bonarelli level and other black shales in the CenomanianTuronian of the northeastern Dolomites (Italy): Calcareous nannofossil and foraminiferal Data. Cretaceous Research 20: 135-167.

Lutz, M.J., Caldeira, K., Dunbar, R.B., Behrenfeld, M.J. 2007. Seasonal rhythms of net primary production and particulate organic carbon flux describe biological pump efficiency in the global Ocean. Journal of Geophysical Research C 112: 10011 (26 p.).

MacEachern, J.A., Bann, K.L., Gingras, M.K., Zonneveld, J.-P., Dashtgard, S.E., Pemberton, S.G. 2012. The ichnofacies paradigm. In: Knaust, D., Bromley, R.G. (Eds.), Trace Fossils as Indicators of Sedimentary Environments. Developments in Sedimentology, 64: 103-138.

Martinez, C., Truillet, R. 1987. Évolution structurale et paléogéographie de la Tunisie. Memoria de la Societa Italiana de Geologia 38: 35-45.

Mejri, F., Burollet, P.F. and Ferjani, A.B. 2006. Petroleum Geology of Tunisia: A Renewed Synthesis. Enterprise Tunisienne d'Activités Pétrolières, Memoir 22. 230p.

Meysman, F.J.R., Galaktionov, O.S., Glud, R.N., Middelburg, J.J. 2010. Oxygen penetration around burrows and roots in aquatic sediments. Journal of Marine Research 68: 309-336.

Middelburg, J.J. 2018. Reviews and syntheses: To the bottom of carbon processing at the seafloor. Biogeosciences 15: 413-427.

Miller, W., d'Alberto, D. 2001. Paleoethologic implications of Zoophycos from Late Cretaceous and Paleocene limestones of the Venetian Prealps, northeastern Italy. Palaeogeography, Palaeoclimatology, Palaeoecology 166: 237-247.

Monaco, P., Bracchini, L., Rodríguez-Tovar, F.J., Uchman, A., Coccioni, R.O. 2017. Evolutionary trend of Zoophycos morphotypes from the Upper Cretaceous-Lower Miocene in the type pelagic sections of Gubbio. Lethaia 50: 41-57.

Mulder, T., Alexander, J. 2001. The physical character of subaqueous sedimentary density flows and their deposits. Sedimentology 48: 269-299.

Myrow, P.M., Southard, J.B. 1996. Tempestite deposition. Journal of Sedimentary Research 66: 875887.

Negra, M.H. 1994. Les dépôts de plate-forme á bassin du Crétacé Supérieur en Tunisie centroseptentrionale (Formation Abiod et faciés associés), stratigraphie, sédimentation, diagenése et intérêt pétrolier. Thése Doctoral, Université de Tunis, 649 p.

Olivero, D. 1996. Zoophycos distribution and sequence stratigraphy. Examples from the Jurassic and Cretaceous deposits of southeastern France. Palaeogeography, Palaeoclimatology, Palaeoecology 123: 273-287.

Olivero, D. 2003. Early Jurassic to Late Cretaceous evolution of Zoophycos in the French Subalpine Basin (southeastern France). Palaeogeography, Palaeoclimatology, Palaeoecology 192: 59-78.

Olivero, D., Gaillard, C. 2007. A constructional model for Zoophycos. In: Miller, W., III. (Ed.), Trace Fossils: 466-477. Amsterdam: Elsevier.

Rebesco, M., Hernández-Molina, F.J., van Rooij, D., Wåhlin, A. 2014. Contourites and associated sediments controlled by deep-water circulation processes: State-of-the-art and future considerations. Marine Geology 352: 111-154.

Richiano, S. 2015. Environmental factors affecting the development of the Zoophycos ichnofacies in the Lower Cretaceous Río Mayer Formation (Austral Basin, Patagonia). Palaeogeography, Palaeoclimatology, Palaeoecology 439: 17-26.

Rodríguez-Tovar, F. J., Löwemark, L., Pardo-Igúzquiza, E. 2011. Zoophycos cyclicity during the last $425 \mathrm{ka}$ in the northeastern South China Sea: Evidence for monsoon fluctuation at the Milankovitch scale. Palaeogeography, Palaeoclimatology, Palaeoecology 305: 256-263. 
Seilacher, A. 1967. Fossil behavior. Scientific American 217: 72-83.

Seilacher, A. 2007. Trace Fossil Analysis. Berlin, Heidelberg: Springer.

Shanmugam, G. 2013. New perspectives on deep-water sandstones: Implications. Petroleum Exploration and Development 40: 316-324.

Shanmugam, G. 2016. Slides, slumps, debris flows, turbidity currents, and bottom currents. In: Reference Module in Earth Systems and Environmental Sciences, 87 p. Amsterdam: Elsevier.

Shanmugam, G. 2017. Contourites: Physical oceanography, process sedimentology, and petroleum geology. Petroleum Exploration and Development 44: 183-216.

Simpson, S. 1970. Notes on Zoophycos and Spirophyton. In: Crimes, T.P., Harper, J.C. (Eds), Trace Fossils. Geological Journal, Special Volume 3: 505-514.

Uchman, A., Demírcan, H. 1999. A Zoophycos group trace fossil from Miocene flysch in southern Turkey: Evidence for a U-shaped causative burrow. Ichnos 6: 251-259.

Wetzel, A., Werner, F. 1980. Morphology and ecological significance of Zoophycos in deep-sea sediments off NW Africa. Palaeogeography, Palaeoclimatology, Palaeoecology 32: 185-212.

Wetzel, A. 2010. Deep-sea ichnology: Observations in modern sediments to interpret fossil counterparts. Acta Geologica Polonica 60: 125-138.

Wetzel, A., Tjallingii, R., Wiesner, M.G. 2011. Bioturbational structures record environmental changes in the upwelling area off Vietnam (South China Sea) for the last 150,000 years. Palaeogeography, Palaeoclimatology, Palaeoecology 311: 256-267.

Wetzel, A., Uchman, A. 2012. Hemipelagic and pelagic basin plains. In: Knaust, D., Bromley, R.G. (Eds.), Trace Fossils as Indicators of Sedimentary Environments. Developments in Sedimentology, 64: 673-701.

Zhang, L.-J., Fan, R.-Y., Gong, Y.-M. 2015. Zoophycos macroevolution since 541 Ma. Scientific Reports 5: 14954.

Zhang, L.J., Shi, G.R., Gong, Y.-M. 2015. An ethological interpretation of Zoophycos based on Permian records from South China and southeastern Australia. Palaios 30: 408-423. 